\title{
Does intellectual property rights protection affect UK and US outward FDI and earnings from FDI? A sectoral analysis
}

\author{
Glauco De Vita ${ }^{1}$, Constantinos Alexiou ${ }^{2}$, Emmanouil Trachanas ${ }^{3}$, Yun Luo ${ }^{4}$ \\ ${ }^{1}$ Centre for Business in Society, Coventry University, Coventry CV1 5FB, UK. E-mail: \\ glauco.devita@coventry.ac.uk. \\ ${ }^{2}$ Cranfield School of Management, Cranfield University, Cranfield MK43 0AL, UK. E-mail: \\ constantinos.alexiou@cranfield.ac.uk. \\ ${ }^{3}$ Oxford Brookes Business School, Oxford Brookes University, Oxford OX3 0BP, UK. E- \\ mail: etrachanas@brookes.ac.uk. \\ ${ }^{4}$ Southampton Business School, University of Southampton, Highfield, Southampton SO17 \\ 1BJ, UK. E-mail: Y.Luo@ soton.ac.uk.
}

Journal of Economic Studies: DOI: 10.1108/JES-09-2021-0462

Accepted 8/11/2021

\section{Structured Abstract}

Purpose: Despite decades of research, the relationship between intellectual property rights (IPRs) and FDI remains ambiguous. Using a recently developed patent enforcement index (along with a broader IPR index) and a large sectoral country-to-country FDI dataset, we revisit the FDI-IPR relationship by testing the impact of IPRs on UK and US outward FDI flows as well as earnings from outward FDI.

Design/methodology/approach: We use disaggregated data for up to 9 distinct sectors of economic activity from both the US and UK for outward FDI flows and earnings from outward FDI, for a panel of up to 42 developed and developing countries over sample periods from 1998 to 2015. We employ a panel fixed effects approach that allows us to exploit the longitudinal properties of the data using Driscoll and Kraay's (1998) nonparametric covariance matrix estimator.

Findings: We do not find any consistent evidence in support of the hypothesis that countries' strength of IPR protection or enforcement affects inward FDI, or that sector of investment matters. Our results prove robust to sensitivity checks that include an alternative broader measure of IPR strength, analyses across sub-samples disaggregated according to the strength of countries' IPRs as well as developing vs. developed economies, and an extended 
specification accounting for dynamic effects of the response of FDI to both previous investment levels and IPR (patent) protection.

Originality: We make use of the largest most granular sectoral country-to-country FDI dataset employed to date in the analysis of the FDI-IPR nexus with disaggregated data for outward FDI and earnings from outward FDI across up to 9 distinct sectors of economic activity from both the US and UK. We employ a more sophisticated measure of IPR strength, the patent index proposed by Papageorgiadis et al. (2014), which places emphasis on the effectiveness of enforcement practices as perceived by managers, together with the overall administrative effectiveness and efficiency of the national patent system.

Keywords: Intellectual property rights; Patents; Foreign direct investment; Multinationals JEL classification: C23; F21; F23; O34 


\section{Introduction}

Foreign Direct Investment (FDI) by Multinational Corporations (MNCs) sits at the heart of economic globalization and is a major catalyst to economic growth. Knowledge of whether and how Intellectual Property Rights (IPRs) affect FDI is, therefore, paramount. The international exploitation of Intellectual Property (IP) is central for FDI across borders, as MNCs strive to exploit their IP-related assets internationally. The incongruence between the growing need for international exploitation of IP and the territorial and often underdeveloped nature of IPRs, especially in developing and transition economies, has led to pressures for systemic change in recent years at national and supranational level. These pressures underpin extensive bilateral, regional and multilateral negotiations on IPRs, leading to a significant expansion of required minimum standards, especially in developing and transition economies. Such expansion culminated in the World Trade Organization's (WTO) Agreement on TradeRelated Aspects of Intellectual Property Rights (TRIPS). Although this movement, which is consistent with processes of globalization through the reduction of barriers to FDI, should have attenuated problems with the legal frameworks involved in the protection of IPRs, concerns related to the harmonization of IPR regimes across countries and continuing difficulties in protecting IP-related assets associated with deficiencies in the enforcement of IPRs remain.

Against this backcloth, and despite several decades of research on the IPR-FDI nexus, the relationship between the two remains ambiguous. As pointedly noted by the recent review article by Noon, De Vita and Appleyard (2019), conflicting theoretical predictions on how the strength of a country's IPR system can affect MNCs' FDI location choice have been hypothesized over the years and, taken collectively, the empirical literature is equally contradictory and inconclusive. 
Three main reasons have been attributed responsibility for the inability of previous applied work to reach a consensus on the relationship between IPRs and FDI. First, since the work of Mansfield (1994), it has been advanced that the importance of IPRs on MNCs' FDI decision varies markedly across sectors of economic activity (see, e.g., Maskus, 2000). Nevertheless, even recent contributions on the IPR-FDI nexus still tend to focus exclusively on manufacturing industry FDI at aggregate level (e.g., Papageorgiadis et al., 2020). Indeed, only few studies have used sector-disaggregated data to test for the role of industry sector in the FDI-IPR relationship (see Park and Lippoldt, 2003; Javorcik, 2004; Nunnenkamp and Spatz, 2004; Nicholson, 2007; Ushijima, 2013; Watkins and Taylor, 2010) and their findings are conflicting.

Second, scarcity of quality FDI data has led to systematic inconsistencies in measurement across most previous studies, often plaguing the reliability of reported results (Noon et al., 2019). In particular, aggregate FDI measures based on count data or the net accumulated stock of FDI provide insufficiently precise measures to gauge how FDI responds to changes in IPRs over time, especially when short sample periods - which in many papers are restricted to one, two or three years (see, e.g., Ferrantino, 1993; Mansfield, 1995; Braga and Fink, 1998; Maskus, 2000; Nunnenkamp and Spatz, 2004; Seyoum, 2006; Nicholson, 2007; Watkins and Taylor, 2010) - are considered. Most importantly, although firms' FDI location decisions are mostly driven by the profitability of their FDIs rather than volume per $s e$, it is striking that no study to date has employed a country's firms earnings from FDI as a measure that would more closely reflect the extent to which a host country's strength of IPR protection might affect MNCs' profitability from FDI and, hence, their propensity to further invest in those countries.

Third, the measurement of the strength of IPR protection has been a thorny issue (Noon et al., 2019). Rapp and Rozek's (1990) index only accounts for one type of IP, patents. 
The Ginarte and Park (1997) and Park (2008) indices extend the mapping of the measurement of patent protection to different categories but their aggregate score of IPR protection strength still constitutes a de jure measure solely based on how IPR laws are written 'on the books' thereby neglecting the crucial de facto enforcement of such laws. The application of dissuasive penalties against those firms found to be violating other firms' IPRs, is an element also ignored in studies using counts of IPR reform or treaties crudely captured by dummy variables (see, e.g., Branstetter et al., 2007; Canals and Şener, 2014).

We break new ground in revisiting the relationship between IPRs and FDI by specifically addressing the limitations of previous work. Three main innovations underlie our contribution. First, we make use of disaggregated outward FDI (OFDI) flows data across up to 9 distinct sectors of economic activity from both the US and UK (in addition to total manufacturing and aggregate OFDI flows), alongside analogous data for earnings from OFDI (EOFDI) for each of these two countries, to a panel of up to 42 developed and developing countries over sample periods from 1998 to 2015. This is by far the largest and most granular country-to-country, sectoral FDI dataset employed to date in the analysis of the FDI-IPR nexus. In the absence of qualitative, firm-level data on MNCs' FDI motivations and type of FDI, sectoral disaggregation - as suggested by many authors (e.g., Nunnenkamp and Spatz, 2004) - becomes paramount to distinguish between FDI arising from MNCs from industries with higher and those with lower technological intensity and IP-content. Indeed, although there is no fully developed industry-level theory of FDI defining the appropriability regime of industry-specific technologies, it appears reasonable to allow for the possibility that MNCs from high IP-content and R\&D intensive industries such as chemicals and pharmaceuticals may be more concerned about IPRs than MNCs from industries such as transportation and storage. As such, our sectoral disaggregation offers a lens to investigate whether aggregate results may mask different effects across industries. Additionally, our complementary 
adoption of data on FDI earnings by industry sectors more accurately captures how IPR protection affects sectoral FDI location decisions given that earnings on equity investments (profitability) may differ across sectors.

Second, we employ a more sophisticated measure of IPR strength, the patent index (IPS) proposed by Papageorgiadis et al. (2014), which places emphasis on the effectiveness of enforcement practices as perceived by managers, together with the overall administrative effectiveness and efficiency of the national patent system. While the investment chapters of recent Bilateral Investment Treaties (BITs) and Free Trade Agreements (FTAs) include IP rights within their scope of application, it is the host country's domestic enforcement of such internationally agreed rights that matters to foreign investing firms. This makes our domestic measure of patent enforcement the most informative to detect how a country's IPR protection may affect FDI location (country) decisions. For robustness and comparative purposes, we also use a broader, aggregate index of IPR strength (IPRI) published by the Property Rights Alliance (PRA), which includes copyrights and trademarks (see

\section{https://www.internationalpropertyrightsindex.org/).}

Finally, our analysis advances on previous econometric specifications and estimation methods in several respects. Our models include most variables hypothesized to have explanatory power on FDI determination. Additionally, whilst prior analyses of IPR-FDI models have hardly ever been concerned with the problem of cross-sectional dependence which can have non-trivial consequences for the reliability of estimation and hypothesis testing - we use fixed-effects (FE) regression models with Driscoll and Kraay (1998) standard errors that allow to alleviate problems of cross-sectional (spatial) and temporal dependence.

Our main results, that prove robust to a battery of sensitivity analyses, do not show any consistent evidence in support of the hypothesis that the strength of IPRs or patent 
enforcement affect UK or US FDI into developed or developing economies, irrespective of industry and host country characteristics.

\section{A synthesis of related literature}

There is no general theory of the relationship between FDI and IPRs. Nevertheless, several frameworks and hypotheses exist offering often contrasting views on how firms' FDI location choice may be induced or deterred by strong or weak IPR protection in host countries. For example, Dunning's (1977, 1979a, 1979b, 2000) Ownership (O), Location (L), and Internalization (I) (OLI) paradigm, an FDI framework frequently applied to the analysis of the IPR-FDI nexus, leads to conflicting predictions on the relationship between a country's strength of IPR protection and inward FDI. On the one hand, the OLI paradigm suggests that strong IPR protection can be considered a country's 'location advantage' in that by reducing the risk of local imitation thanks to greater enforcement of MNCs' IP-related 'ownership advantages', it enhances FDI attraction. On the other hand, when examined through the lens of the 'internalization' element, strong IPR protection can be expected to affect negatively inward FDI by inducing MNCs to choose licensing agreements with producers in developing countries over FDI (Braga and Fink, 1998). Following this logic, FDI would be preferred only under weak IPR protection in host countries because internalized production would allow MNCs to maintain greater direct control over their IP-related assets (Ferrantino, 1993). It follows that despite its usefulness in highlighting some possible channels through which firms' FDI may be induced or deterred by the strength of IPRs of host environments, the OLI paradigm does not lead to determinate predictions.

Some complex, partial- or dynamic general-equilibrium models have also been developed to examine the effects of IPRs on FDI-driven technology transfer from Northern MNCs into the developing world, 'the South' (e.g., Grossman and Helpman, 1991; Helpman, 
1993; Lai, 1998; Markusen, 2001; Glass and Saggi, 2002; Glass and Wu, 2007; Branstetter and Saggi, 2011; Yang, 2013; Mathew and Mukherjee, 2014; Tanaka and Iwaisako, 2014). Varying and often contrasting simplifying assumptions underlie these models, including whether subsidies are considered, innovation is treated as a 'quality improvement' or a 'variety expansion', the MNC is regarded as an industry leader or a follower, a third developing country is included in the model, and whether imitation is treated as costless and/or endogenously determined. Overall, also as a result of the different assumptions, these economic models studying the effects of strengthened IPRs in 'the South' on FDI by Northern MNCs, are divided as to whether developing countries would attract greater FDI.

Against this backcloth, we conclude that given the many different theoretical channels postulated and conflicting effects hypothesized, the aggregate net effect of the strength of IPR protection on FDI attraction remains theoretically ambiguous.

Taken collectively, the empirical literature has failed to square such theoretical ambiguity, with many studies finding positive (Mansfield, 1994, and 1995; Lee and Mansfield, 1996; Maskus, 2000; Nunnenkamp and Spatz, 2004; Javorcik, 2004; Seyoum, 2006; Park and Lippoldt, 2003; Branstetter et al., 2007; Adams, 2010; Hsu and Tiao, 2015) as well as negative or statistically insignificant effects (Ferrantino, 1993; Kondo, 1995; Seyoum, 1996; Braga and Fink, 1998; Mayer and Pfister, 2001; Fosfuri, 2004; Watkins and Taylor, 2010).

The mixed findings are puzzling but as noted by Nunnenkamp and Spatz (2004, p. 395), 'there are various reasons to suspect that the impact of IPR protection on FDI is blurred unless industry characteristics and host-country conditions are taken into account'. Indeed, since the work of Mansfield (1994), it has been advanced that the strength of the IPR-FDI relationship may depend on the technological intensity characterizing the type of FDI and the industry of investment. Mansfield (1994 and 1995) found that the importance of IPRs on 
MNCs' FDI decision varies markedly across industries, with it being much greater for firms in the chemical, pharmaceutical, machinery, and electrical equipment industries. Braga and Fink (1998) too emphasized that without strong IPR protection, MNCs may be deterred from investing in sectors with high IP content such as R\&D and technology-intensive manufacturing processes. Maskus (2000) observed that FDI in lower technology goods and services, such as textiles and apparel, electronic assembly, and distribution, depends much less on the strength of IPR protection than on input costs and market opportunities. FDI in products or technologies that entail a high cost of imitation may also reduce the importance of IPR regimes in FDI location decisions. On the other hand, FDI in easily imitable products and technologies, such as pharmaceuticals, chemicals and software, is more sensitive to the strength of IPRs. This proposition explains Maskus' call $(2000, \mathrm{p} .15)$ 'the need is acute for sectoral breakdowns of investment'.

Yet, partly due to data limitations, contributions based on sectoral breakdowns of FDI continue to be rare (see, e.g., Papageorgiadis et al., 2020, which focuses exclusively on US manufacturing outward FDI). Only a handful of studies have employed sectoral data to test the mediating role of industry characteristics in the relationship between IPRs and FDI. Moreover, the limited evidence based on sector-disaggregated data is not univocal. Whilst Park and Lippoldt (2003), Javorcik (2004), Nunnenkamp and Spatz (2004) and Ushijima (2013) seem to agree that IPRs have a positive and significant effect on FDI only in technology and R\&D intensive industries that rely heavily on IPR protection, Nicholson's (2007) results suggest that firms in industries with high capital costs are more likely to maintain control over production knowledge through FDI in countries with weak IPR regimes while when IPRs are strong, firms in industries with high investment in R\&D are more likely to enter a market by alternative market entry modes. To muddy the waters further, Watkins and Taylor (2010), whose analysis benefits from a disaggregation of FDI data across many 
industrial sectors, conclude that their results consistently fail to support the hypothesis that emerging economy IPRs strongly affect the level or distribution of advanced country FDI.

\section{Estimation method and model}

We test the impact of IPRs on US and UK outward FDI (OFDI) flows as well as earnings from OFDI (EOFDI) on a large panel of countries. The underlying logic for investigating whether IPRs may affect EOFDI stems from the possibility that while IPRs may not have an impact on the quantity or volume of FDI, they may correlate with the profitability of any such investment. After all, MNCs' appropriation of returns for their FDI in areas such as $\mathrm{R} \& \mathrm{D}$ and innovation is inevitably contingent on the existence of patent-related legislation in the legal framework of countries as well as the ability of government agents and institutional actors to enforce it. Taking earnings from OFDI as an additional FDI measure could, therefore, unveil - particularly in our sectoral level analysis - interesting correlations precisely because industries which rely on distinct technologies or high IP content may, under different appropriability regimes, experience different profitability levels than industries which undertake less R\&D and are less concerned with IPR protection.

The US was an obvious choice as our headquarters country of reference, it being the largest source economy of outward FDI and the one most frequently used in past papers studying the effects of IPRs in the developing world on FDI by MNCs from the North. The US is also one of the few countries that makes publicly available reliable and comprehensive estimates of FDI financial transactions at sectoral level (which are rare to come by and very hard to assemble) via the Bureau of Economic Analysis (BEA). But, of course, it seemed opportune to take one more source country as a consistency check in our analysis. Inspection of the data at the UK Office for National Statistics (ONS), confirmed that we would be able to compile an adequately sized and sufficiently comparable dataset of reliable sectoral level 
country-to-country OFDI flows and EOFDI for the UK. The UK too is highly representative, ranking fourth among all world economies in terms of FDI outflows (UNCTAD, 2018, p. 6), making it another suitable source country for our analysis.

A serious issue likely to apply across the units of panel data made up of countries considered in IPR-FDI regressions that is largely ignored in previous studies, is crosssectional dependence, which can arise due to spatial or spillover effects and have serious consequences for the reliability of estimation and validity of hypothesis testing. Accordingly, at the preliminary stage of our analysis we tested for cross-sectional dependence (CSD) using Pesaran's (2015) CSD test. The significant test results (not reported to conserve space) showed support for the alternative hypothesis of 'strong crosssectional dependence' in both data samples. This means that, in addition to removing entirely the time dimension information of our longitudinal data panel (paramount to capture the evolution of FDI as well as IPR indices over time), performing cross-sectional estimation as done in several previous studies on the IPR-FDI nexus would lead, by ignoring the dependence of regression disturbances between cross-sectional units, to biased statistical inference (Pesaran, 2005; Hoechle, 2007). Furthermore, as observed by Hoechle (2007, p. 282), 'standard error estimates of commonly applied covariance matrix estimation techniques $[\ldots]$ are biased, and hence statistical inference on such standard errors is invalid.' It is for these reasons that we employ a fixed effects approach that allows us to exploit the longitudinal properties of the data, using Driscoll and Kraay's (1998) nonparametric covariance matrix estimator, which produces heteroscedasticity- and autocorrelationconsistent standard errors that are robust to cross-sectional and temporal dependence. The coefficient estimates resulting from this approach are not only consistent but also efficient (Hoechle, 2007). 
Estimation is undertaken on an unbalanced panel at annual frequency, following a standard specification:

$$
\begin{aligned}
& \text {OFDIF }_{i t}=a_{0}+\xi_{i t} X_{i t}+\varepsilon_{i t} \\
& \text { OFDIE }_{i t}=\beta_{0}+\gamma_{i t} X_{i t}+e_{i t}
\end{aligned}
$$

where $O F D I F_{i t}$ is outward FDI flows per sector to the selected economies, and $O F D I E_{i t}$ is earnings from outward FDI. For the UK, our sample consists of 18 economies (Brazil; Canada; China; France; Germany; Hong Kong, China; India; Ireland; Italy; Japan; Malaysia; Netherlands; Norway; Singapore; Spain; Sweden; Switzerland; USA) over the period 19982015. For the USA, we benefit from a larger sample of 42 countries (Argentina; Australia; Austria; Belgium; Brazil; Canada; Chile; China; Colombia; Czech Republic; Denmark; Finland; France; Germany; Greece; Hong Kong, China; Hungary; India; Indonesia; Ireland; Israel; Italy; Japan; South Korea; Malaysia; Mexico; Netherlands; New Zealand; Norway; Philippines; Poland; Portugal; Russia; Singapore; South Africa; Spain; Sweden; Switzerland; Thailand; Turkey; United Kingdom; Venezuela) over 1999-2014.

The recipient countries used for the empirical investigation are the most representative as they attract substantial FDI flows from UK and US firms. Specifically, the percentage of UK FDI flows to these countries and earnings from FDI as a share of UK's total FDI flows and total earnings from FDI, are 66 and 68\%, respectively. For the US dataset, these percentages are both approximately $67 \%$.

\section{Data}

\subsection{FDI data}

Outward foreign direct investment flows $\left(O F D I_{i t}\right)$ relate to investments by a US/UK person or resident company in a non-US/UK affiliate or branch. In accordance with international 
guidelines (e.g., OECD, 1996), foreign investment must be at least $10 \%$ of the ordinary shares or voting power.

The net FDI earnings data $(E O F D I i t)$ are a measure of the returns that investors obtain from FDI after deduction of provisions for depreciation and taxes on profits. For the US dataset, they are based on the aggregation of data items reported on BEA's direct investment surveys by US MNCs for US direct investment abroad. Such FDI income receipts and payments consist of income received by US parent companies and affiliates who own assets classified in the direct investment functional category. Income measures the return that parents and affiliates receive on their equity and debt investments and consists of the parents' shares of the earnings and losses from current operations of affiliates plus interest received and paid on intercompany debt (BEA, 2014). Similarly, the UK EOFDI data sourced from ONS are based on the annual FDI surveys to businesses, in line with the Statistics of Trade Act 1947. FDI earnings are net values measuring the profits and interest generated by the direct investor (parent company) from their affiliates. Such survey data are complemented by and cross-checked against data from the Bank of England for all monetary financial institutions and other sources for property and public corporations in FDI. Survey responses are used to impute EOFDI values for every company in the UK's outward FDI populations. Reliability of such annual survey data is further ensured by larger sample sizes than the quarterly surveys. Response rates are also analyzed by proportion of Net Book Value received and by industry sector and size band following the Standard Industrial Classification (SIC), which allows for a precise assignment of industry sector categorization.

Our sectoral disaggregation is based on the industry classification of the MNC rather than the subsidiary, inevitably so given the features of available data. Yet, this should not constitute an issue given that relatively few subsidiaries are creating new technologies, more commonly transferred by the MNC's headquarters. We have made every effort to incorporate 
in our analysis the contribution of the largest sectors in terms of OFDI flows and EOFDI. For the UK sample, due to data limitations we have resorted to selecting 9 sectors plus 'Total Manufacturing' (and an aggregate measure of total OFDI flows and EOFDI) out of the 17 reported in the ONS' annual bulletins. These are: food, beverages and tobacco; petroleum, chemicals, pharmaceuticals, rubber, plastic; textiles and wood; metal and machinery; retails and wholesale trade, repair of motor vehicles and motor cycles; other manufacturing; transportation and storage; financial services; construction; and total manufacturing. The selected sectors account for $84 \%$ of UK OFDI flows and $72 \%$ of UK EOFDI out of all UK sectors.

For the US dataset, we selected 16 sectors out of the 71 currently reported in BEA's annual industry economic accounts but to allow tractability and achieve greater consistency with the UK sample we aggregate them into 8 sectors plus 'Total manufacturing'. The selected 16 (but aggregated into 8) sectors account for 91\% of both US OFDI flows and US EOFDI out of all US sectors. These are: mining; food; chemicals; primary fabricated metals; machinery; other manufacturing; computers, electrical and transportation; other industry; and total manufacturing.

It is worth noting that the intention to incorporate more sectors and more countries in our dataset was hampered by the many missing values in both the ONS and BEA databases due to data suppressed to avoid disclosure of data of individual companies, and absolute values not reported if less than $£ 500,000 / \$ 500,000$ in the respective UK/US databases. Evidently, we can do nothing about this feature of the data but as noted above our datasets cover approximately two thirds of the whole population of OFDI flows and EOFDI of US and UK MNCs. Moreover, as shown in Table 2a, for the UK aggregate sample $(\mathrm{N}=18$, $\mathrm{T}=18$ ), we only lose six observations due to missing values for $O F D I_{i t}$ (318 observations available for estimation out of 324 of a full sample) and only two for EOFDI $I_{\text {it }}$ (322 
observations available). Similarly, for the aggregate US sample (N=42, T=16, see Table 2b) we only record 11 missing values for $O F D I_{i t}$ and no missing values at all for $E O F D I_{i t}$ (the full 672 observations are available for estimation), thus offering adequate reassurances.

\subsection{Measures of IPRs}

We advance on the norm of outdated IPR indices such as Park (2008), which does not consider the effectiveness of patent enforcement in practice in courts and other areas of policing the law (see, e.g., Brander et al., 2017), by employing the IPR enforcement index (Papageorgiadis et al., 2014, henceforth IPS) that provides estimates of the level of transaction costs that IP-owning firms face when engaging with a national patent system (for a recent application of this index on how the strength of IP institutions affects Chinese outward FDI, see Alexiou \& Vogiazas, 2021). The data used to quantify the components of an IP system include items such as the effectiveness of judicial and police enforcement and the level of corruption in the judiciary that measure the perceptions of IP asset owners of how enforcement agents behave in IPR regimes. As recently noted by Papageorgiadis et al. (2020), 'These perceptions capture the unwritten rules that influence how enforcement agents operate in legal arenas.'

For comparative purposes, we also use the International Property Rights index (henceforth IPRI) that is published annually (since 2007) by the Property Rights Alliance (an index also recently used by Malen and Vaaler, 2017). The IPRI index has three core components: a) legal and political environment; b) physical property rights; c) intellectual property rights (protection of IPRs, patent protection, copyright piracy). IPRI scores and rankings are based on data obtained from official sources made publicly available by established international organizations. It should be noted that all these IPR country indices are based on annual data, thus they already account for country level shifts in IPR regulation (e.g., IPR reforms) and the effects of global influences on national IPR legislation such as 
multilateral treaties and international or regional agreements (e.g., accession to WTO, ASEAN, NAFTA) covering the application of IP rights to FDI promotion and protection.

\subsection{Other FDI determinants}

Equations (1) and (2) also include $X_{i t}$, a vector of variables accounting for other FDI determinants (see Table 1) amply used in FDI literature (see, e.g., Cushman and De Vita, 2017), namely, population as a proxy for market size $\left(P O P_{i t}\right)$, GDP growth to capture the rate of economic development $\left(G D P_{i t}\right)$, openness proxied by trade-to-GDP ratio $\left(T R A D E_{i t}\right)$, inflation as measure of macroeconomic stability $\left(I N F_{i t}\right)$, the KPMG corporate tax rate ( CORTAX $X_{i t}$ ), industry as a measure of industrial development of a country ( INDU $\left.U_{i t}\right)$, the 'rate of change' (log form) of the annual period average exchange rate (defined as annual average spot exchange rate of the national currency into pound sterling/USD) from one year to the next, an exchange rate measure which solves the scaling problem of cross-sectional heterogeneity $\left(E X R C_{i t}\right)$, fixed telephone subscriptions to capture the level of information infrastructure $\left(I N F R A_{i t}\right)$, exports of goods from the UK/US to partner countries $\left(E X P_{i t}\right)$, educational attainment as a proxy for human capital $\left(E D U C_{i t}\right)$, and political stability as a measure of the perception of the likelihood of political instability and/or politically-motivated violence, including terrorism $\left(P S A V T_{i t}\right)$. Additional controls and dynamic effects as they pertain to how OFDI and EOFDI may respond to previous levels of investment and IPR protection are accounted for in our robustness regressions.

Table 1 provides a description of all variables and sources. Tables $2 \mathrm{a}$ and $2 \mathrm{~b}$ present descriptive statistics for the UK and US samples, respectively, and Table 3 describes the sectors considered.

[Tables 1, 2a, 2b, 3 about here] 


\section{Results}

We begin by considering regressions on OFDI flows for both the UK and US, presented in Table $4 \mathrm{a}$ and $4 \mathrm{~b}$, respectively. For the UK sample, the property rights coefficients (IPS) are statistically insignificant on aggregate (column 1) and across all sectors (columns 2 to 11) with the sole exceptions of 'Transportation and storage' ('TS' in column 8) with an estimated coefficient of -3.846 statistically significant at the $1 \%$ level, and 'Metal and machinery products' ('MM' in column 5) with an estimate of 1.749 significant at $10 \%$. A similar result is obtained from the US data sample (Table 4b), where the IPS coefficient is only significant at $10 \%$ on 'Aggregate' ( -0.499 , in column 1$)$, and at $1 \%$ for the 'Food' sector ('F', in column 4) with an estimated coefficient of -0.865 .

\section{[Tables $4 a$ and $4 b$ about here]}

A similar pattern of no relationship between IPRs (IPS) and FDI emerges from our regressions on UK (Table 5a) and US (Table 5b) earnings from outward FDI (EOFDI). As shown in Table 5a, the only significant IPS coefficient at any credible statistical level (5\% or less) pertains to 'Textiles and Wood activities' ('TW', in column 3) with an estimated coefficient of -1.096 , and 'Construction' (' $\mathrm{C}$ ', in column 10) with an estimated coefficient of -1.157. These results are consistent with those of Table 5b for the US sample, where none of the IPS coefficients are significant.

\section{[Tables 5a and $5 b$ about here]}

To interrogate the data further, we regress OFDI flows for both the UK (Table 6a) and US (Table 6b) on samples disaggregated according to high (Panel A) and low (Panel B) IPS regimes (based on the median IPS sample value), respectively. Given that our central interest here lies in detecting the correlation between IPR protection and FDI, to conserve space, from now on our tables of results do not report the estimated coefficients of all other control variables albeit included in the regressions. Panel A of Table 6a displays some negative 
estimated coefficients at reasonable significance levels (5\% or less), namely, 'Aggregate' OFDI flows in column 1 (-4.225**), 'Textiles and wood activities' ('TW') in column 3 (6.174***), and 'Transportation and storage' ('TS') in column 8 (-7.206**). These results are somewhat puzzling since host country conditions characterized by strong IPR protection (high IPS regime) should not, theoretically, discourage UK OFDI flows, especially in sectors that do not entail high IP content or R\&D such as 'TW' and 'TS'. The potentially spurious nature of the significant coefficients reported in Panel A of Table 6a is corroborated by the results of Panel B, for a low IPS regime, where none of the IPS coefficients (with the sole exception of ' $\mathrm{TW}$ ' in column 3) is found to be statistically significant. Turning our attention to the US sample (Table 6b), under a high IPS regime (Panel A), no significant relationship is detected between IPS and OFDI flows across the ten regressions, and only 'Primary fabricated metals' ('PFM', in column 6) with an estimated coefficient of -0.729 is significant (at 5\%) in the ten regressions under a low IPS regime (Panel B).

\section{[Tables 6a and $6 \mathrm{~b}$ about here]}

We repeat these latest estimations using EOFDI as the dependent variable for both the UK and US, with the results presented in Table $7 \mathrm{a}$ and $7 \mathrm{~b}$, respectively. For the UK, under a high IPS regime (Panel A), no estimated coefficient is statistically significant, while for a low IPS regime (Panel B) the only statistically significant coefficients out of the eleven regressions are for ' $\mathrm{TW}$ ' in column 3 with a value of -1.248 (significant at $1 \%$ ) and 'Construction' (' $\mathrm{C}$ ' in column 10) with a value of -2.023 (significant at $5 \%$ ). For the US sample (Table 7b), under a high IPS regimes (Panel A), only three out of the ten regressions record statistically significant values (all at 5\%). These pertain to 'Mining' in column 2 (1.483), 'Total manufacturing' in column 3 (0.646) and 'Computers, electrical and transportation' in column 9 (1.127). However, none of the IPR (IPS) coefficients in Panel B, under a low IPS regime, are significant at any reasonable level (1 or 5\%). 


\section{[Tables $7 \mathrm{a}$ and $7 \mathrm{~b}$ about here]}

Overall, therefore, our results do not show any consistent evidence in support of the hypothesis that the strength of IPRs affects UK or US OFDI flows or EOFDI, at both aggregate and sectoral level. Indeed, aside from few sporadic exceptions - and mostly under a high IPS regime where we would least expect IPR protection to discourage FDI - sectoral estimates are statistically insignificant with no clear or robust pattern emerging in support of the proposition that without strong IPR protection MNCs may be deterred from investing in sectors with high IP content such as R\&D and technology-intensive manufacturing processes.

As for comparison with previous empirical studies claiming a significant IPR-FDI relationship, as noted in our review of past applied work, we rationalize the discrepancy in terms of unreliable past inferences based predominantly on cross-sectional estimations that are invalid in the presence of cross-sectional dependence, often rudimentary measures employed to capture IPR protection, and the use of aggregate FDI data that do not allow for a sectoral, country-to-country FDI-IPR panel econometric set up in estimation. That said, among the mixed results reported in previous literature, our findings align to those by Watkins and Taylor (2010) who tested the effect of IPRs on US FDI in 22 emerging economies from 2006 to 2008. They used the Ginarte and Park (1997) index and the survey based IPR index of the World Economic Forum (WEF). Their various multivariate models, based on FDI data disaggregated across nine industries and eight sectors within the manufacturing industry, also provided no support to the hypothesis that emerging economies' IPRs affect the level or distribution of advanced country FDI. Like Watkins and Taylor (2010), we conclude that this result may be due to the fact that IPRs may simply be insufficiently significant for a large majority of the industries involved in FDI or that the influence of IPRs may be heavily outweighed by the broader set of determinants that influence MNCs’ FDI location decisions. 


\section{Further analysis and robustness}

By way of robustness we extend the analysis in three ways. First, we check the sensitivity of our results to an alternative IPR measure, the International Property Rights index (IPRI) published annually (since 2007) by the Property Rights Alliance. Second, although we have already conducted regressions on disaggregated datasets for our UK and US samples according to high and low IPS regimes, we now test the OFDI and EOFDI response to the strength of IPR (IPS) protection with respect to developed versus developing countries, an analysis which due to data limitations will be restricted to the US dataset.

Finally, we check the sensitivity of our results (based on a parsimonious model aimed at avoiding over-parameterization) to potentially omitted variables and introduce dynamic effects in a new robustness model specification. Specifically, to account for OFDI or EOFDI potentially responding to previous levels of investment, we include a lagged term of FDI stock, the total accumulated value of foreign-owned assets at period t-1. Another permutation pertains to the possibility of a dynamic response of FDI to IPR protection. Theoretically, how IPR protection affects particularly profit from FDI is not unambiguous. Our previous analysis assumed a contemporaneous correlation. Yet, as it is the case for FDI possibly responding to previous investment levels, it appears opportune to investigate also the possibility that OFDI and especially EOFDI may respond to IPR protection with a lag. Accordingly, in these robustness regressions we also include, in addition to patent enforcement in the current period, the lagged IPS index. The last model extension entails accounting explicitly for the knowledge production in various host countries as an opportunity for knowledge sourcing by US MNCs by including as an additional control the level of R\&D (R\&D) and, to gauge the level of innovation intensity, the host country's total patent applications (PATENT). 
Starting with the estimations based on the broader IPR index (IPRI), Tables $8 \mathrm{a}$ and $8 \mathrm{~b}$ report the regression results for the UK and US OFDI samples, respectively. For UK OFDI, only three columns out of eleven display statistically significant IPRI coefficients ('TW' in column 3, 'PCPRP' in column 4, and 'TRM' in column 7) but with the exception of PCPRP ('Petroleum, chemicals, pharmaceuticals, rubber, plastic products') which is negatively signed at only significant at $10 \%(-2.285)$, the other estimated coefficients are positive, a result at odds with a priori theory. For US OFDI (Table $8 \mathrm{~b}$ ), the only statistically significant IPRI coefficient (only at the $10 \%$ level) is 'TM' in column 3 (-1.621). Re-estimations based on UK and US EOFDI are reported in Tables 9a and 9b. For UK EOFDI, once again, most of the IPRI coefficients are insignificant at any credible statistical level, with the sole exception of the 'FBT' sector in column 2, which is negatively signed and significant at 5\% (-5.213), 'TW' in column 3, and ' $\mathrm{C}$ ' in column 10. A similar pattern is found for US EOFDI (Table 9b), where out of ten regressions none displays a significant IPRI coefficient at 1 or $5 \%$.

\section{[Tables 8a, 8b, 9a and 9b about here]}

Next, we disaggregate the US sample into developed $v s$. developing countries. ${ }^{1}$ According to previous literature (e.g., Ginarte and Park, 1997) weak IPR protection in developing countries may discourage inward FDI, particularly in technology and R\&D intensive industries. Yet, the results presented in Table 10 show that US OFDI flows are unaffected by the strength of IPR protection (patent enforcement) in either developed (Panel A) or developing countries (Panel B). Table 11 repeats the estimations with US EOFDI as the dependent variable. Looking at the developed countries, in Panel A, the four significant IPS coefficients ('Aggregate', 'Total manufacturing', 'Food', and 'Computers, electrical and transportation') are all positively signed. Nevertheless, for developing countries (Panel B),

\footnotetext{
${ }^{1}$ Our categorisation of developed $v s$. developing countries is based on the IMF classification (https://www.imf.org/external/pubs/ft/weo/2018/02/weodata/weoselgr.aspx).
} 
the only regression displaying a significant coefficient (negatively signed), and at only 10\%, is 'Mining' (-0.630), a sector where imitative ability and hence IPR protection would not be expected to play a significant role on MNCs' earnings from FDI.

\section{[Tables 10 and 11 about here]}

Finally, we extend the model with other controls and by including dynamic effects. As can be seen from Table 12a (on US OFDI) and 12b (on US EOFDI), going by the adjusted 'R-squared within' values, the respective regressions of this extended specification do not appear to better explain the variance within the panel units each regression accounts for, and do not display results significantly different from those obtained thus far. For OFDI flows, each of the newly added variables, lagged FDISTOCK, R\&D and PATENT, is only statistically significant at reasonable levels in, at most, three out of the ten regressions. Most importantly, none of the estimated IPS coefficients is significant at 5\% or less, and only for 'TM' (column 3) a significant coefficient is recorded for $I P S_{t-1}$.

\section{[Tables 12a and 12b about here]}

A broadly similar picture emerges from Table $12 \mathrm{~b}$ on EOFDI where none of the IPS and $I P S_{t-1}$ are significant at reasonable statistical levels in 'Aggregate' (column 1), for total 'Total Manufacturing' (column 3) and for the majority of the remaining sectors. Interestingly though, the newly added independent variables, expenditure on R\&D and total patent applications, both display a significant coefficient for the 'Aggregate' impact (column 1) on profitability from FDI, positively and negatively signed, respectively $\left(0.580^{* * ;}-0.435^{* *}\right)$, suggesting that the higher the level of host country R\&D, the higher foreign investors' profitability from FDI, while greater market competition in patented innovations reduces MNCs' returns from FDI.

\section{Concluding discussion}


We revisited the still unsettled question of the impact of IPRs on FDI using a recently developed patent enforcement index, and a comprehensive UK and US dataset on outward FDI (OFDI) flows as well as earnings from OFDI (EOFDI) to a large panel of countries over 1998-2015, the most granular sectoral country-to-country sectoral FDI dataset employed to date in the analysis of the FDI-IPR nexus.

We find no consistent evidence in support of the hypothesis that host country IPRs affect FDI, or that sector of investment matters. Our results prove robust to many sensitivity checks that include an alternative, broader measure of IPR strength, analyses across subsamples disaggregated according to the strength of countries' IPRs as well as developing $v s$. developed economies, and an extended specification accounting for dynamic effects of the response of FDI to both previous investment levels and IPR (patent) protection. These findings suggest that the strength of IPR protection - even accounting for the all-important aspect of enforcement - may be, after all, less important than is generally considered for most industries involved in FDI.

In rationalizing our evidence we concur with Maskus' (1998) original insight that IPRs alone may generate insufficiently strong incentives for MNCs to invest (or not to invest) in a country due to more important country factors influencing MNCs' FDI location decisions. Of course, there may be other explanations for the lack of correlation unveiled by our data. For example, IPRs may be irrelevant to FDI because they exert contemporaneous offsetting effects on firms' FDI decisions. But it is somewhat unlikely that such offsetting effects would produce consistently inconsequential net impacts on alternative measures of FDI (flows as well as earnings from FDI), across most industries and for investments by both US and UK MNCs. We, therefore, lend more credence to our first interpretation of the evidence. Either way, the key implication for public and business policies, is that IPRs do not matter much, both in the wider host country's regulatory framework to enable inward FDI or 
for MNCs' FDI location choice and profitability of such investment, irrespective of industry sector.

Although our finding questions many of the orthodoxies suggesting that IPR protection may significantly deter FDI, it helps square the puzzling paradox of why, despite a persistent perception of weak IPR protection, countries like China are receiving large amounts of global FDI flows, also from countries like the US and UK, and even in sensitive areas such as R\&D. Indeed, in spite of China's highly publicized poor reputation for IPR protection and enforcement, China has been consistently ranked as one of the world's top two recipient economies of FDI inflows over the past two decades, suggesting that IPR protection (or enforcement) is not, by itself, a significant determinant of FDI.

Evidently, in line with our interpretation, despite the complexity and difficulties of operating in China, including concerns about IPRs, factors such as the size of the market override such concerns, which is why China remains an important market for US and UK MNCs' FDI. Moreover, as observed by Zhao (2006), technologies developed by US MNCs with R\&D investing in China (or in other weak IPR countries we would expect), mostly developed at MNC headquarters rather than at subsidiary level, tend to be part of a 'closely knit internal innovation structure' (Zhao, 2006, p. 1185) of the MNC, which serves as a sort of 'immune system' (ibid, p. 1185) against the inadequate protection of external institutions and regulations of host countries with weak IPRs; an insight consistent with our evidence and which offers another explanation for the finding of IPRs being statistically unrelated to FDI.

In conclusion, IPR reform dictated by a global push for uniformity notwithstanding, countries keen to increase FDI attraction would be better off concentrating on policies aimed at enhancing their FDI-related regulatory frameworks, their investment promotion strategy, the quality of infrastructure and the availability of skilled labor. Mindful of the importance of the kind or 'quality' of FDI to attract, and benefits to be accrued via spillover effects, host 
countries governments' efforts should also focus on improving absorptive capacity and on creating a favorable ecosystem for science, technology and innovation.

Despite the reliability of our results, few caveats need to be borne in mind when interpreting our findings. First, our data and country-to-country econometric set up prevented us from explicitly controlling for firm motive, the structure of MNCs and their boundaries. Controlling for such factors would require qualitative survey data at firm level, which are not readily available. Nevertheless, our sectoral disaggregation goes some way to capturing how differences between firms in high-tech sectors (that may be less inclined to transfer frontier technology and hence more concerned about IPRs) and firms in low-tech sectors (that may be simply looking for a low-cost base), may affect the sensitivity of FDI to IPR protection. Second, our choice of two source countries constrained by data availability, prevented us from explicitly controlling for whether it is 'IPR protection' itself or 'IPR distance' that matters in FDI location decisions. Yet, since one would expect IPR regimes to matter more for US and UK investing firms than to investing firms from countries with weaker IPRs and lower technological innovations, we can safely infer that 'South-South' FDI - being susceptible to even lower 'IPR distance' between source and host country - would be unlikely to yield different results. Finally, our analysis was constrained by a feature of the data that assigns industry measurement based on the industry of the MNC rather than the subsidiary, meaning that the sector is pre-determined. Yet, for horizontal integration and with the increasing advancement of global value chains, the importance of IPRs may also differ depending on whether technology is being transferred across sectors in host economies. Data availability permitting, including sectorally disaggregated IPR indices, these caveats provide a stimulating agenda for future research.

Conflict of interest - The authors have no conflict of interest. 


\section{References}

Adams, S. (2010). Intellectual property rights, investment climate and FDI in developing countries. International Business Research, 3(3), 201-209.

Alexiou, C., \& Vogiazas, S. (2021). European intellectual property institutions and Chinese foreign direct investment. Journal of Economic Studies, 48(2), 296-312.

BEA (2014). U.S. International Economic Accounts: Concepts and Methods. Bureau of Economic Analysis (BEA), U.S. Department of Commerce. Available at: https://www.bea.gov/sites/default/files/methodologies/ONE\%20PDF\%20-\%20IEA\%20 Concepts \%20Methods.pdf\#page $=128$

Braga, C.A.P., \& Fink, C. (1998). The relationship between intellectual property rights and foreign direct investment. Duke Journal of Comparative \& International Law, 9(1), 163-187. https://heinonline.org/HOL/P?h=hein.journals/djcil9\&i=169

Brander, J.A., Cui, V., \& Vertinsky, I. (2017). China and intellectual property rights: A challenge to the rule of law. Journal of International Business Studies, 48(7), 908-921. https://doi.org/10.1057/s41267-017-0087-7

Branstetter, L., \& Saggi, K. (2011). Intellectual property rights, foreign direct investment and industrial development. Economic Journal, 121(555), 1161-1191. https://doi.org/10.1111/j.1468-0297.2011.02440.x

Branstetter, L., Fisman, R., Foley, C.F., \& Saggi, K. (2007). Intellectual property rights, imitation, and foreign direct investment: Theory and evidence. NBER Working Paper No. 13033. National Bureau of Economic Research. Cambridge, MA. https://doi.org/10.3386/w13033

Canals, C., \& Şener, F. (2014). Offshoring and intellectual property rights reform. Journal of Development Economics, 108(C), 17-31. https://doi.org/10.1016/j.jdeveco.2014.01.001

Cushman, D.O., \& De Vita, G. (2017). Exchange rate regimes and FDI in developing countries: A propensity score matching approach. Journal of International Money and Finance, 77(C), 143-163. https://doi.org/10.1016/j.jimonfin.2017.07.018

Driscoll, J.C., \& Kraay, A.C. (1998). Consistent covariance matrix estimation with spatially dependent panel data. The Review of Economics and Statistics, 80(4), 549-560. https://doi.org/10.1162/003465398557825 
Dunning, J.H. (1977). Trade, location of economic activity and the MNE: A search for an eclectic approach. In: Ohlin, B., Hesselborn, P.O., Wijkman, P.M. (Eds.), The international allocation of economic activity. Macmillan, London, pp. 395-418.

Dunning, J.H. (1979a). Explaining changing patterns of international production: in defense of the eclectic theory. Oxford Bulletin of Economics and Statistics 41(4), 269-295. https://doi.org/10.1111/j.1468-0084.1979.mp41004003.x

Dunning, J.H. (1979b). Toward an eclectic theory of international production: some empirical tests. Journal of International Business Studies, 11(1), 9-31. https://doi.org/10.1057/palgrave.jibs.8490593

Dunning, J.H. (2000). The eclectic paradigm as an envelope for economic and business theories of MNE activity. International Business Review, 9(2), 163-190. https://doi.org/10.1016/S0969-5931(99)00035-9

Ferrantino, M.J. (1993). The effect of intellectual property rights on international trade and investment. Weltwirtschaftliches Archiv, 129(2), 300-331.

https://www.jstor.org/stable/40440200

Fosfuri, A. (2004). Determinants of international activity: Evidence from the chemical processing. Research Policy, 33(10), 1599-1614. https://doi.org/10.1016/j.respol.2004.09.003

Ginarte, J.C., \& Park, W.G. (1997). Determinants of patent rights: A cross-national study. Research Policy, 26(3), 283-301. https://doi.org/10.1016/S0048-7333(97)00022-X

Glass, A.J., \& Saggi, K. (2002). Intellectual property rights and foreign direct investment. Journal of International Economics, 56(2), 387-410. https://doi.org/10.1016/S00221996(01)00117-9

Glass, A.J., \& Wu, X. (2007). Intellectual property rights and quality improvement. Journal of Development Economics, 82(2), 393-415. https://doi.org/10.1016/j.jdeveco.2005.08.002

Grossman, G.M., \& Helpman, E. (1991). Innovation and growth in the global economy. MIT Press, Cambridge, MA.

Helpman, E. (1993). Innovation, imitation and intellectual property rights. Econometrica, 61(6), 1247-1280.

Hoechle, D. (2007). Robust standard errors for panel regressions with cross-sectional dependence. The Stata Journal, 7(3), 281-312. https://doi.org/10.1177/1536867X0700700301 
Hsu, J., \& Tiao, Y.E. (2015). Patent rights protection and foreign direct investment in Asian countries. Economic Modelling, 44(C), 1-6. https://doi.org/10.1016/j.econmod.2014.08.018

Javorcik, B.S. (2004). The composition of foreign direct investment and protection of intellectual property rights: Evidence from transition economies. European Economic Review, 48(1), 39-62. https://doi.org/10.1016/S0014-2921(02)00257-X

Kondo, E.K. (1995). The effect of patent protection on foreign direct investment. Journal of World Trade, 29(6), 97-122.

Lai, E. L.-C. (1998). International intellectual property rights protection and the rate of product innovation. Journal of Development Economics, 55(1), 133-153. https://doi.org/10.1016/S0304-3878(97)00059-X

Lee, J.-Y., \& Mansfield, E. (1996). Intellectual property protection and US foreign direct investment. The Review of Economics and Statistics, 78(2), 181-186. https://doi.org/10.2307/2109919

Malen, J., \& Vaaler, P.M. (2017). Organizational slack, national institutions and innovation effort around the world. Journal of World Business, 52(6), 782-797. https://doi.org/10.1016/j.jwb.2017.07.001

Mansfield, E. (1994). Intellectual property protection, foreign direct investment, and technology transfer. International Finance Corporation, Discussion Paper No. 19. The World Bank, Washington, DC. Available at: http://documents.worldbank.org/curated/en/888591468739296453/Intellectualproperty-protection-foreign-direct-investment-and-technology-transfer

Mansfield, E. (1995). Intellectual property protection, foreign direct investment, and technology transfer - Germany, Japan, and the United States. International Finance Corporation, Discussion Paper No. 27. The World Bank, Washington, DC.

Markusen, J.R. (2001). Contracts, intellectual property rights, and multinational investment in developing countries. Journal of International Economics, 53(1), 189-204. https://doi.org/10.1016/S0022-1996(00)00058-1

Maskus, K.E. (1998). The role of intellectual property rights in promoting foreign direct investment and technology transfer. Duke Journal of Comparative and International Law, 9(1), 109-161.

Maskus, K.E. (2000). Intellectual property rights and foreign direct investment. Policy Discussion Paper No. 0022. Centre for International Economic Studies. University of Adelaide. 
Mathew, A.J., \& Mukherjee, A. (2014). Intellectual property rights, southern innovation and foreign direct investment. International Review of Economics and Finance, 31(C), 128137. https://doi.org/10.1016/j.iref.2013.11.004

Mayer, T., \& Pfister, E. (2001). Do stronger patent rights attract foreign direct investment? Evidence from French multinationals' location. Region et Developpement, 13, 99-122.

Nicholson, M.W. (2007). The impact of industry characteristics and IPR policy on foreign direct investment. Review of World Economics, 143(1), 27-54. https://doi.org/10.1007/s10290-007-0097-9

Noon, P., De Vita, G., \& Appleyard, L. (2019). What do we know about the impact of intellectual property rights on the foreign direct investment location (country) choice? A review and research agenda. Journal of Economic Surveys 33(2), 665-688. https://doi.org/10.1111/joes.12292

Nunnenkamp, P., \& Spatz, J. (2004). Intellectual property rights and foreign direct investment: A disaggregated analysis. Review of World Economics, 140(3), 393-414. https://doi.org/10.1007/BF02665982

OECD (1996). Benchmark Definition of Foreign Direct Investment (3 ${ }^{\text {rd }}$ Ed.). OECD Publishing, Paris.

Papageorgiadis, N., Cross, A.R., \& Alexiou, C. (2014). International patent systems strength 1998-2011. Journal of World Business, 49(4), 586-597. https://doi.org/10.1016/j.jwb.2013.12.011

Papageorgiadis, N., McDonald, F., Wang, C., \& Konara, P. (2020). The characteristics of intellectual property rights regimes: How formal and informal institutions affect outward FDI location. International Business Review, 29(1). https://doi.org/10.1016/j.ibusrev.2019.101620

Park, W.G. (2008). International patent protection: 1960-2005. Research Policy, 37(4), 761766. https://doi.org/10.1016/j.respol.2008.01.006

Park, W.G., \& Lippoldt, D. (2003). The impact of trade-related intellectual property rights on trade and foreign direct investment in developing countries. OECD Papers, 3(11), 140.

Pesaran, M.H. (2015). Testing weak cross-sectional dependence in large panels. Econometric Reviews, 34(6-10), 1089-1117. https://doi.org/10.1080/07474938.2014.956623

Rapp, R.T., \& Rozek, R.P. (1990). Benefits and costs of intellectual property protection in developing countries. Working Paper No. 3. National Economic Research Associates, Inc., White Plains, NY. 
Seyoum, B. (1996). The impact of intellectual property rights on foreign direct investment. Columbia Journal of World Business, 31(1), 51-59. https://doi.org/10.1016/S00225428(96)90006-X

Seyoum, B. (2006). Patent protection and foreign direct investment. Thunderbird International Business Review, 48(3), 389-404. https://doi.org/10.1002/tie.20101

Tanaka, H., \& Iwaisako, T. (2014). Intellectual property rights and foreign direct investment: A welfare analysis. European Economic Review, 67(C), 107-124. https://doi.org/10.1016/j.euroecorev.2014.01.013

UNCTAD (2018). World Investment Report 2018. United Nations, New York and Geneva, https://unctad.org/en/PublicationsLibrary/wir2018 en.pdf.

Ushijima, T. (2013). Patent rights protection and Japanese foreign direct investment. Research Policy, 42(3), 738-748. https://doi.org/10.1016/j.respol.2012.09.010

Watkins, J.M., \& Taylor, M.Z. (2010). Intellectual property protection and US foreign direct investment in emerging economies. Journal of Intellectual Property Rights, 15(6), 415428. http://nopr.niscair.res.in/handle/123456789/10684

Yang, Z. (2013). Intellectual Property Rights Protection, Complexity and Multinational Firms. Munich Personal RePEc Archive, MPRA Paper No. 46734. Available at: https://mpra.ub.uni-muenchen.de/id/eprint/46734

Zhao, M. (2006). Conducting R\&D in countries with weak intellectual property rights protection. Management Science, 52(8), 1185-1199. https://doi.org/10.1287/mnsc.1060.0516 
Table 1 Description of variables.

\begin{tabular}{|c|c|c|}
\hline Variable & Description & Source \\
\hline OFDI & $\begin{array}{l}\text { Total net foreign direct investment flows abroad } \\
\text { analyzed by area and main country }\end{array}$ & $\begin{array}{l}\text { UK Office for National Statistics (1998- } \\
\text { 2015) and US Bureau of Economic Analysis } \\
(1999-2014)\end{array}$ \\
\hline EOFDI & $\begin{array}{l}\text { Total earnings from foreign direct investment } \\
\text { abroad analyzed by area and main country }\end{array}$ & $\begin{array}{l}\text { UK Office for National Statistics (1998- } \\
\text { 2015) and US Bureau of Economic Analysis } \\
(1999-2014)\end{array}$ \\
\hline IPS & $\begin{array}{l}\text { Papageorgiadis et al. (2014) index of patent } \\
\text { systems strength }\end{array}$ & $\begin{array}{l}\text { Papageorgiadis et al. (2014) (1998-2014), } \\
\text { https://www.cranfield.ac.uk/som/research- } \\
\text { projects/index-of-patent-systems-strength- } \\
\text { 1998-2015 }\end{array}$ \\
\hline IPRI & International property rights index & $\begin{array}{l}\text { Property Rights Alliance (2007-2015), } \\
\text { https://www.internationalpropertyrightsindex } \\
\text {.org/ }\end{array}$ \\
\hline CORTAX & KPMG corporate tax rate & $\begin{array}{l}\text { KPMG's Corporate and Indirect Tax Rate } \\
\text { Survey } 2007 \text { and } 2011 \text { (UK: 2003-2015; US: } \\
\text { 1999-2015), } \\
\text { https://home.kpmg.com/xx/en/home/services } \\
\text { /tax/tax-tools-and-resources/tax-rates- } \\
\text { online/corporate-tax-rates-table.html }\end{array}$ \\
\hline$I N D U$ & Industry, value added (annual percentage growth) & $\begin{array}{l}\text { World Development Indicators, World Bank } \\
(1998-2015)\end{array}$ \\
\hline$E X R C$ & $\begin{array}{l}\text { The rate of change of the annual average spot } \\
\text { exchange rate national currency into pound } \\
\text { sterling/dollar }\end{array}$ & $\begin{array}{l}\text { United Nations Conference on Trade and } \\
\text { Development (1998-2015) }\end{array}$ \\
\hline INFRA & Fixed telephone subscriptions (per 100 people) & World Development Indicators (1998-2015) \\
\hline INF & Inflation, consumer prices (annual \%) & World Development Indicators (1998-2015) \\
\hline$G D P$ & GDP growth to capture the level of development & World Development Indicators (1998-2015) \\
\hline POP & The natural logarithm of total population & World Development Indicators (1998-2015) \\
\hline$T R A D E$ & Openness proxied by trade-to-GDP ratio & World Development Indicators (1998-2015) \\
\hline$E X P$ & $\begin{array}{l}\text { The natural logarithm of exports of goods from the } \\
\text { UK/US to partners (trade value in US dollars) }\end{array}$ & United Nations Comtrade (1998-2015) \\
\hline$E D U C$ & $\begin{array}{l}\text { Educational attainment as a proxy of level of } \\
\text { human resource from Barro and Lee version } 2016 \\
\text { educational attainment tertiary (\% total population, } \\
\text { age } 15+\text { ). The raw observations are at five-year } \\
\text { intervals through } 2010 \text {. We use interpolation (and } \\
\text { extrapolation for 2011-2015) to fill in the gaps. }\end{array}$ & $\begin{array}{l}\text { Barro-Lee website (1998-2014), } \\
\text { http://www.barrolee.com/ }\end{array}$ \\
\hline PSAVT & $\begin{array}{l}\text { Political stability and absence of } \\
\text { violence/terrorism, measuring perceptions of the } \\
\text { likelihood of political instability and/or politically } \\
\text { motivated violence, including terrorism ( }-2.5 \text { weak } \\
\text { to }+2.5 \text { strong). }\end{array}$ & $\begin{array}{l}\text { Worldwide Governance Indicators (1998, } \\
\text { 2000, 2002-2015) }\end{array}$ \\
\hline $\begin{array}{l}\text { FDISTOC } \\
K\end{array}$ & The natural logarithm of stock of FDI inflow & $\begin{array}{l}\text { United Nations Conference on Trade and } \\
\text { Development (1998-2015) }\end{array}$ \\
\hline$R \& D$ & $\begin{array}{l}\text { Gross domestic expenditures on research and } \\
\text { development (R\&D), expressed as a percent of } \\
\text { GDP }\end{array}$ & World Development Indicators (1998-2015) \\
\hline PATENT & $\begin{array}{l}\text { The natural logarithm of total patent applications } \\
\text { (direct and PCT national phase entries) }\end{array}$ & $\begin{array}{l}\text { WIPO IP Statistics Data Centre } \\
\text { https://www3.wipo.int/ipstats/keyindex.htm }\end{array}$ \\
\hline
\end{tabular}


Table 2a Summary statistics for UK sample.

\begin{tabular}{|c|c|c|c|c|c|}
\hline & $\begin{array}{l}\text { Obs } \\
\end{array}$ & Mean & SD & Min & Max \\
\hline \multicolumn{6}{|l|}{ Panel A: Variables } \\
\hline OFDI & 318 & 3.51 & 5.25 & -9.06 & 11.01 \\
\hline EOFDI & 322 & 5.49 & 3.08 & -7.17 & 9.44 \\
\hline IPS & 306 & 7.40 & 1.66 & 4.10 & 9.40 \\
\hline$I P R I$ & 161 & 7.14 & 1.13 & 4.40 & 8.50 \\
\hline$E X R C$ & 324 & -0.001 & 0.091 & -0.674 & 0.423 \\
\hline$E D U C$ & 306 & 20.83 & 11.52 & 3.29 & 53.94 \\
\hline$G D P$ & 324 & 3.10 & 3.66 & -7.36 & 26.28 \\
\hline$I N F$ & 324 & 2.20 & 2.39 & -4.48 & 14.72 \\
\hline$T R A D E$ & 324 & 108.74 & 104.89 & 16.44 & 455.42 \\
\hline CORTAX & 324 & 29.90 & 8.26 & 12.50 & 56.66 \\
\hline$I N D U$ & 311 & 2.60 & 7.18 & -15.37 & 90.43 \\
\hline PSAVT & 288 & 0.60 & 0.69 & -1.52 & 1.66 \\
\hline INFRA & 324 & 43.45 & 18.18 & 1.99 & 74.76 \\
\hline$E X P$ & 324 & 22.98 & 1.05 & 20.83 & 24.99 \\
\hline$P O P$ & 324 & 17.52 & 1.75 & 15.12 & 21.03 \\
\hline \multicolumn{6}{|l|}{ Panel B: Sectors - OFDI } \\
\hline Food products, beverages and tobacco products & 214 & 1.93 & 4.46 & -8.86 & 8.95 \\
\hline Textiles and wood activities & 237 & 1.02 & 2.98 & -7.65 & 7.44 \\
\hline Petroleum, chemicals, pharmaceuticals, rubber, plastic products & 252 & 1.87 & 4.29 & -8.62 & 9.44 \\
\hline Metal and machinery products & 298 & 1.48 & 3.21 & -7.43 & 8.02 \\
\hline Other manufacturing & 304 & 1.30 & 3.67 & -8.70 & 8.26 \\
\hline $\begin{array}{l}\text { Retails and wholesale trade, repair of motor vehicles and } \\
\text { motorcycles }\end{array}$ & 294 & 1.63 & 3.96 & -7.77 & 9.18 \\
\hline Transportation and storage & 271 & 1.33 & 4.02 & -8.91 & 10.80 \\
\hline Financial services & 291 & 2.35 & 5.05 & -8.94 & 9.97 \\
\hline Construction & 280 & 1.68 & 3.63 & -7.48 & 8.49 \\
\hline Total manufacturing & 317 & 2.50 & 4.85 & -8.79 & 9.86 \\
\hline \multicolumn{6}{|l|}{ Panel C: Sectors - EOFDI } \\
\hline Food products, beverages and tobacco products & 186 & 3.35 & 3.52 & -7.38 & 8.60 \\
\hline Textiles and wood activities & 232 & 1.93 & 2.33 & -5.80 & 8.42 \\
\hline Petroleum, chemicals, pharmaceuticals, rubber, plastic products & 241 & 3.83 & 2.51 & -5.63 & 8.44 \\
\hline Metal and machinery products & 297 & 2.81 & 1.83 & -4.14 & 7.20 \\
\hline Other manufacturing & 287 & 2.75 & 2.05 & -4.42 & 7.22 \\
\hline $\begin{array}{l}\text { Retails and wholesale trade, repair of motor vehicles and } \\
\text { motorcycles }\end{array}$ & 275 & 2.98 & 2.63 & -7.10 & 7.97 \\
\hline Transportation and storage & 267 & 1.86 & 3.18 & -6.41 & 8.72 \\
\hline Financial services & 295 & 4.10 & 3.47 & -8.29 & 8.55 \\
\hline Construction & 299 & 2.84 & 2.47 & -4.72 & 7.87 \\
\hline Total manufacturing & 322 & 4.68 & 2.82 & -7.29 & 9.12 \\
\hline
\end{tabular}

Note: Descriptive statistics for the full UK sample of 324 observations $(\mathrm{N}=18 ; \mathrm{T}=18)$. 
Table 2b Summary statistics for US sample.

\begin{tabular}{|c|c|c|c|c|c|}
\hline & Obs. & Mean & SD & Min & Max \\
\hline \multicolumn{6}{|l|}{ Panel A: Variables } \\
\hline OFDI & 661 & 5.27 & 5.27 & -9.95 & 11.60 \\
\hline EOFDI & 672 & 7.32 & 2.20 & -6.90 & 11.27 \\
\hline IPS & 672 & 6.39 & 2.11 & 2.24 & 9.90 \\
\hline$I P R I$ & 333 & 6.51 & 1.46 & 2.86 & 8.65 \\
\hline$E X R C$ & 656 & 0.01 & 0.12 & -0.33 & 1.14 \\
\hline$E D U C$ & 672 & 19.39 & 10.56 & 2.06 & 59.22 \\
\hline$G D P$ & 671 & 3.05 & 3.45 & -10.89 & 18.28 \\
\hline$I N F$ & 671 & 4.31 & 7.18 & -4.48 & 85.74 \\
\hline$T R A D E$ & 672 & 89.73 & 73.08 & 18.34 & 442.62 \\
\hline CORTAX & 670 & 28.78 & 6.86 & 12.50 & 52.30 \\
\hline$I N D U$ & 661 & 2.45 & 5.20 & -18.12 & 25.25 \\
\hline PSAVT & 672 & 0.30 & 0.94 & -2.37 & 1.76 \\
\hline INFRA & 672 & 36.20 & 18.28 & 2.13 & 74.76 \\
\hline$E X P$ & 672 & 9.10 & 1.33 & 6.22 & 12.65 \\
\hline$P O P$ & 672 & 17.19 & 1.41 & 15.14 & 21.04 \\
\hline FDISTOCK & 664 & 47.98 & 65.30 & 1.01 & 542.49 \\
\hline$R \& D$ & 590 & 1.52 & 1.02 & 0.05 & 4.43 \\
\hline PATENT & 669 & 8.72 & 1.62 & 4.77 & 13.74 \\
\hline \multicolumn{6}{|l|}{ Panel B: Sectors - OFDI } \\
\hline Mining & 479 & 1.69 & 4.27 & -7.98 & 9.35 \\
\hline Food & 508 & 1.91 & 3.39 & -6.45 & 8.96 \\
\hline Chemicals & 643 & 2.81 & 3.97 & -8.25 & 8.75 \\
\hline Primary fabricated metals & 499 & 1.47 & 3.07 & -7.27 & 7.52 \\
\hline Machinery & 557 & 2.04 & 3.43 & -6.80 & 8.15 \\
\hline Computers, electrical and transportation & 672 & 2.05 & 4.50 & -8.76 & 8.63 \\
\hline Other manufacturing & 280 & 3.23 & 4.38 & -8.75 & 9.40 \\
\hline Other industry & 672 & 4.02 & 5.28 & -9.97 & 11.39 \\
\hline Total manufacturing & 661 & 4.43 & 4.36 & -8.57 & 9.69 \\
\hline \multicolumn{6}{|l|}{ Panel C: Sectors - EOFDI } \\
\hline Mining & 540 & 2.73 & 3.31 & -6.35 & 8.56 \\
\hline Food & 608 & 2.84 & 2.40 & -4.99 & 7.02 \\
\hline Chemicals & 642 & 4.37 & 2.23 & -5.48 & 8.25 \\
\hline Primary fabricated metals & 600 & 2.02 & 2.27 & -5.65 & 6.24 \\
\hline Machinery & 615 & 2.92 & 2.31 & -4.34 & 6.84 \\
\hline Computers, electrical and transportation & 672 & 3.30 & 3.64 & -8.63 & 8.48 \\
\hline Other manufacturing & 409 & 4.52 & 2.28 & -4.38 & 8.59 \\
\hline Other industry & 672 & 6.05 & 3.01 & -7.17 & 11.21 \\
\hline Total manufacturing & 668 & 5.86 & 2.41 & -7.39 & 9.37 \\
\hline
\end{tabular}

Note: Descriptive statistics for the full US sample of 672 observations $(\mathrm{N}=42 ; \mathrm{T}=16)$. 
Table 3 UK and US sectors and abbreviations.

\begin{tabular}{ll} 
UK sectors & Abbreviations \\
\hline Food products, beverages and tobacco products & FBT \\
Textiles and wood activities & TW \\
Petroleum, chemicals, pharmaceuticals, rubber, plastic products & PCPRP \\
Metal and machinery products & MM \\
Other manufacturing & OM \\
Retails and wholesale trade, repair of motor vehicles and motorcycles & TRM \\
Transportation and storage & TS \\
Financial services & FS \\
Construction & C \\
Total manufacturing & TM \\
\hline & \\
US sectors & Abbreviations \\
\hline Mining & M \\
Food & F \\
Chemicals & C \\
Primary fabricated metals & PFM \\
Machinery & MA \\
Computers, electrical and transportation & CET \\
Other manufacturing & OM \\
Other industry & OI \\
Total manufacturing & TM \\
\hline
\end{tabular}


Table 4a Dependent variable OFDI flows - UK sample.

\begin{tabular}{|c|c|c|c|c|c|c|c|c|c|c|c|}
\hline & (1) & (2) & (3) & (4) & (5) & (6) & (7) & (8) & (9) & (10) & (11) \\
\hline & Aggregate & FBT & TW & PCPRP & MM & $\mathrm{OM}$ & TRM & TS & FS & C & $\mathrm{TM}$ \\
\hline \multirow[t]{2}{*}{$I P S$} & -0.821 & -1.497 & -0.493 & 0.156 & $1.749 * *$ & -0.759 & 1.021 & $-3.846 * * *$ & -0.995 & 1.349 & -0.449 \\
\hline & $(0.767)$ & $(1.272)$ & (0.668) & (0.948) & $(0.805)$ & (0.943) & $(0.586)$ & $(1.009)$ & (1.254) & (1.155) & (1.184) \\
\hline \multirow[t]{2}{*}{$I N F$} & 0.078 & $0.537 * * *$ & -0.037 & 0.021 & 0.092 & -0.063 & -0.076 & $0.403 *$ & -0.046 & 0.133 & 0.114 \\
\hline & $(0.219)$ & $(0.130)$ & $(0.096)$ & $(0.136)$ & $(0.121)$ & $(0.122)$ & $(0.122)$ & $(0.206)$ & (0.169) & $(0.101)$ & $(0.155)$ \\
\hline \multirow[t]{2}{*}{$G D P$} & 0.180 & $0.612 * *$ & $0.164^{*}$ & -0.046 & 0.022 & $0.302 *$ & 0.061 & 0.053 & 0.254 & 0.048 & 0.244 \\
\hline & $(0.198)$ & $(0.264)$ & $(0.080)$ & $(0.178)$ & $(0.133)$ & (0.163) & (0.118) & $(0.121)$ & $(0.223)$ & $(0.192)$ & $(0.236)$ \\
\hline \multirow[t]{2}{*}{ TRADE } & $-0.042 * *$ & 0.015 & 0.017 & 0.006 & -0.001 & 0.014 & 0.022 & -0.013 & $-0.031 * *$ & $-0.017 * *$ & 0.015 \\
\hline & $(0.014)$ & $(0.022)$ & (0.018) & $(0.015)$ & (0.014) & $(0.011)$ & $(0.015)$ & $(0.011)$ & $(0.014)$ & $(0.008)$ & (0.016) \\
\hline \multirow[t]{2}{*}{ CORTAX } & 0.057 & 0.036 & 0.137 & -0.047 & 0.017 & $-0.162 * *$ & -0.021 & $0.119 *$ & 0.016 & -0.146 & -0.063 \\
\hline & $(0.080)$ & (0.095) & (0.094) & $(0.083)$ & (0.104) & $(0.068)$ & (0.078) & $(0.066)$ & (0.111) & $(0.085)$ & (0.086) \\
\hline \multirow[t]{2}{*}{$I N D U$} & 0.055 & -0.239 & -0.141 & 0.036 & -0.016 & -0.105 & 0.058 & -0.000 & -0.087 & -0.130 & -0.140 \\
\hline & (0.132) & $(0.152)$ & (0.110) & (0.109) & $(0.052)$ & (0.103) & $(0.061)$ & (0.104) & $(0.087)$ & $(0.083)$ & (0.123) \\
\hline$E X R C$ & $\begin{array}{l}3.369 \\
(4.291)\end{array}$ & $\begin{array}{l}1.135 \\
(3.894)\end{array}$ & $\begin{array}{l}-1.757 \\
(1.989)\end{array}$ & $\begin{array}{l}-15.506 * * * \\
(2.342)\end{array}$ & $\begin{array}{l}0.529 \\
(3.577)\end{array}$ & $\begin{array}{l}5.328 \\
(3.220)\end{array}$ & $\begin{array}{l}5.881 * \\
(3.136)\end{array}$ & $\begin{array}{l}-2.936 \\
(5.101)\end{array}$ & $\begin{array}{l}1.906 \\
(3.536)\end{array}$ & $-4.957 * *$ & -2.018 \\
\hline \multirow{2}{*}{$E D U C$} & -0.115 & -0.162 & 0.092 & 0.263 & 0.009 & $-0.175^{* *}$ & -0.022 & $0.239 * *$ & -0.256 & 0.012 & -0.128 \\
\hline & (0.118) & (0.102) & (0.078) & $(0.160)$ & $(0.055)$ & $(0.072)$ & (0.084) & $(0.106)$ & $(0.155)$ & $(0.082)$ & $(0.100)$ \\
\hline \multirow[t]{2}{*}{$P S A V T$} & -1.027 & -1.488 & -0.781 & -0.628 & -0.556 & 0.539 & -2.308 & -2.216 & -0.678 & 2.634 & 1.609 \\
\hline & (1.578) & (1.960) & (1.738) & (1.263) & (1.300) & (2.263) & (1.443) & (2.058) & (2.284) & (1.962) & (2.599) \\
\hline \multirow[t]{2}{*}{ INFRA } & -0.052 & 0.000 & -0.001 & -0.030 & -0.035 & 0.051 & $0.081 *$ & -0.028 & 0.005 & -0.058 & 0.036 \\
\hline & $(0.085)$ & (0.086) & $(0.062)$ & $(0.047)$ & $(0.037)$ & $(0.033)$ & (0.038) & $(0.053)$ & $(0.047)$ & $(0.061)$ & (0.054) \\
\hline \multirow[t]{2}{*}{$E X P$} & $2.662 * * *$ & 0.106 & -0.217 & $2.712 * * *$ & $1.348 * *$ & $-1.454 * *$ & 0.119 & 0.410 & $3.962 * * *$ & $-1.590 * * *$ & 0.532 \\
\hline & $(0.603)$ & (0.928) & $(0.650)$ & $(0.785)$ & $(0.589)$ & $(0.588)$ & $(0.550)$ & $(0.845)$ & $(0.926)$ & $(0.312)$ & $(0.712)$ \\
\hline \multirow[t]{2}{*}{$P O P$} & -4.568 & -7.529 & $-15.384 * *$ & 10.223 & 4.287 & 7.040 & $22.625 * *$ & -13.699 & 3.570 & $11.613 *$ & -1.901 \\
\hline & (12.558) & (13.033) & $(6.327)$ & $(8.652)$ & $(9.421)$ & (7.934) & $(8.622)$ & $(8.824)$ & (14.295) & (6.487) & (11.043) \\
\hline Constant & $\begin{array}{l}37.036 \\
(216.279)\end{array}$ & $\begin{array}{l}143.617 \\
(223.612)\end{array}$ & $\begin{array}{l}275.640 * * \\
(109.637)\end{array}$ & $\begin{array}{l}-240.977 \\
(155.969)\end{array}$ & $\begin{array}{l}-114.496 \\
(159.035)\end{array}$ & $\begin{array}{l}-78.410 \\
(136.361)\end{array}$ & $\begin{array}{l}-408.932 * * \\
(151.032)\end{array}$ & $\begin{array}{l}255.261 \\
(158.491)\end{array}$ & $\begin{array}{l}-137.379 \\
(229.987)\end{array}$ & $\begin{array}{l}-166.544 \\
(110.440)\end{array}$ & $\begin{array}{l}28.282 \\
(190.661)\end{array}$ \\
\hline Observations & 255 & 171 & 186 & 199 & 238 & 243 & 234 & 213 & 233 & 223 & 254 \\
\hline R-squared within & 0.228 & 0.185 & 0.158 & 0.178 & 0.189 & 0.221 & 0.256 & 0.166 & 0.238 & 0.203 & 0.132 \\
\hline
\end{tabular}

Note: Standard errors in parentheses. Time dummies are included in the estimations but not shown here to save space $* * * * *$, and $*$ denote statistical significance at the $1 \%, 5 \%$, and $10 \%$ level, respectively. 
Table 4b Dependent variable OFDI flows - US sample.

\begin{tabular}{|c|c|c|c|c|c|c|c|c|c|c|}
\hline & (1) & (2) & (3) & (4) & (5) & (6) & (7) & (8) & (9) & (10) \\
\hline & Aggregate & M & TM & $\mathrm{F}$ & $\mathrm{C}$ & PFM & MA & OM & CET & OI \\
\hline$I P S$ & $\begin{array}{l}-0.424 \\
(0.285)\end{array}$ & $\begin{array}{l}-0.136 \\
(0.419)\end{array}$ & $\begin{array}{l}-0.059 \\
(0.428)\end{array}$ & $\begin{array}{l}-0.865 * * * \\
(0.285)\end{array}$ & $\begin{array}{l}0.216 \\
(0.463)\end{array}$ & $\begin{array}{l}-0.158 \\
(0.332)\end{array}$ & $\begin{array}{l}-0.044 \\
(0.352)\end{array}$ & $\begin{array}{l}-0.511 \\
(0.766)\end{array}$ & $\begin{array}{l}-0.065 \\
(0.475)\end{array}$ & $\begin{array}{l}-0.219 \\
(0.500)\end{array}$ \\
\hline INF & $\begin{array}{l}-0.069 \\
(0.045)\end{array}$ & $\begin{array}{l}0.023 \\
(0.049)\end{array}$ & $\begin{array}{l}-0.037 \\
(0.052)\end{array}$ & $\begin{array}{l}0.049 \\
(0.031)\end{array}$ & $\begin{array}{l}-0.047 \\
(0.042)\end{array}$ & $\begin{array}{l}0.053 \\
(0.033)\end{array}$ & $\begin{array}{l}0.004 \\
(0.057)\end{array}$ & $\begin{array}{l}-0.090 \\
(0.079)\end{array}$ & $\begin{array}{l}-0.021 \\
(0.025)\end{array}$ & $\begin{array}{l}-0.019 \\
(0.074)\end{array}$ \\
\hline$G D P$ & $\begin{array}{l}0.006 \\
(0.109)\end{array}$ & $\begin{array}{l}-0.020 \\
(0.193)\end{array}$ & $\begin{array}{l}0.140 \\
(0.084)\end{array}$ & $\begin{array}{l}0.013 \\
(0.064)\end{array}$ & $\begin{array}{l}0.100 \\
(0.109)\end{array}$ & $\begin{array}{l}0.038 \\
(0.108)\end{array}$ & $\begin{array}{l}0.010 \\
(0.074)\end{array}$ & $\begin{array}{l}0.143 \\
(0.340)\end{array}$ & $\begin{array}{l}0.111 \\
(0.098)\end{array}$ & $\begin{array}{l}0.175 \\
(0.140)\end{array}$ \\
\hline$T R A D E$ & $\begin{array}{l}-0.020 \\
(0.024)\end{array}$ & $\begin{array}{l}0.001 \\
(0.012)\end{array}$ & $\begin{array}{l}0.013 \\
(0.014)\end{array}$ & $\begin{array}{l}-0.015^{* *} \\
(0.006)\end{array}$ & $\begin{array}{l}0.013 \\
(0.009)\end{array}$ & $\begin{array}{l}-0.010 \\
(0.006)\end{array}$ & $\begin{array}{l}-0.016^{*} \\
(0.009)\end{array}$ & $\begin{array}{l}-0.027 \\
(0.020)\end{array}$ & $\begin{array}{l}0.023 \\
(0.018)\end{array}$ & $\begin{array}{l}-0.026 \\
(0.027)\end{array}$ \\
\hline CORTAX & $\begin{array}{l}0.200 * * \\
(0.076)\end{array}$ & $\begin{array}{l}0.005 \\
(0.073)\end{array}$ & $\begin{array}{l}0.093^{*} \\
(0.048)\end{array}$ & $\begin{array}{l}0.086 \\
(0.062)\end{array}$ & $\begin{array}{l}-0.024 \\
(0.049)\end{array}$ & $\begin{array}{l}-0.081 \\
(0.053)\end{array}$ & $\begin{array}{l}-0.007 \\
(0.046)\end{array}$ & $\begin{array}{l}-0.086 \\
(0.111)\end{array}$ & $\begin{array}{l}0.092^{*} \\
(0.049)\end{array}$ & $\begin{array}{l}0.148^{*} \\
(0.078)\end{array}$ \\
\hline$I N D U$ & $\begin{array}{l}-0.058 \\
(0.056)\end{array}$ & $\begin{array}{l}0.055 \\
(0.087)\end{array}$ & $\begin{array}{l}-0.031 \\
(0.053)\end{array}$ & $\begin{array}{l}-0.037 \\
(0.048)\end{array}$ & $\begin{array}{l}-0.157 * * \\
(0.061)\end{array}$ & $\begin{array}{l}-0.014 \\
(0.038)\end{array}$ & $\begin{array}{l}-0.007 \\
(0.061)\end{array}$ & $\begin{array}{l}-0.082 \\
(0.211)\end{array}$ & $\begin{array}{l}-0.037 \\
(0.071)\end{array}$ & $\begin{array}{l}-0.064 \\
(0.087)\end{array}$ \\
\hline EXRCHAN & $\begin{array}{l}-2.863 \\
(2.334)\end{array}$ & $\begin{array}{l}-4.954 * * \\
(1.829)\end{array}$ & $\begin{array}{l}-1.015 \\
(2.037)\end{array}$ & $\begin{array}{l}-0.496 \\
(1.833)\end{array}$ & $\begin{array}{l}-1.884 \\
(1.514)\end{array}$ & $\begin{array}{l}-1.858^{*} \\
(0.970)\end{array}$ & $\begin{array}{l}-0.172 \\
(1.468)\end{array}$ & $\begin{array}{l}7.241^{*} \\
(3.445)\end{array}$ & $\begin{array}{l}-0.181 \\
(2.317)\end{array}$ & $\begin{array}{l}-0.363 \\
(2.121)\end{array}$ \\
\hline$E D U C$ & $\begin{array}{l}0.028 \\
(0.072)\end{array}$ & $\begin{array}{l}0.045 \\
(0.070)\end{array}$ & $\begin{array}{l}0.101 \\
(0.062)\end{array}$ & $\begin{array}{l}0.094 \\
(0.057)\end{array}$ & $\begin{array}{l}-0.024 \\
(0.043)\end{array}$ & $\begin{array}{l}-0.036 \\
(0.030)\end{array}$ & $\begin{array}{l}0.003 \\
(0.029)\end{array}$ & $\begin{array}{l}0.051 \\
(0.135)\end{array}$ & $\begin{array}{l}0.091 * * \\
(0.041)\end{array}$ & $\begin{array}{l}0.114 * * * \\
(0.031)\end{array}$ \\
\hline PSAVT & $\begin{array}{l}2.351 * * * \\
(0.581)\end{array}$ & $\begin{array}{l}0.828 \\
(0.756)\end{array}$ & $\begin{array}{l}-0.527 \\
(0.626)\end{array}$ & $\begin{array}{l}0.420 \\
(0.337)\end{array}$ & $\begin{array}{l}-0.902 \\
(0.544)\end{array}$ & $\begin{array}{l}-0.762 * \\
(0.419)\end{array}$ & $\begin{array}{l}0.623 \\
(0.532)\end{array}$ & $\begin{array}{l}-0.868 \\
(1.124)\end{array}$ & $\begin{array}{l}0.229 \\
(0.532)\end{array}$ & $\begin{array}{l}1.487 * * \\
(0.521)\end{array}$ \\
\hline INFRA & $\begin{array}{l}0.036 \\
(0.037)\end{array}$ & $\begin{array}{l}0.014 \\
(0.020)\end{array}$ & $\begin{array}{l}0.033 \\
(0.024)\end{array}$ & $\begin{array}{l}0.036 \\
(0.044)\end{array}$ & $\begin{array}{l}0.095 * * * \\
(0.030)\end{array}$ & $\begin{array}{l}0.027 \\
(0.029)\end{array}$ & $\begin{array}{l}-0.013 \\
(0.028)\end{array}$ & $\begin{array}{l}0.097 \\
(0.059)\end{array}$ & $\begin{array}{l}-0.029 \\
(0.018)\end{array}$ & $\begin{array}{l}0.046 \\
(0.046)\end{array}$ \\
\hline$E X P$ & $\begin{array}{l}1.904 * * \\
(0.685)\end{array}$ & $\begin{array}{l}-0.949 \\
(1.067)\end{array}$ & $\begin{array}{l}1.736 * * * \\
(0.504)\end{array}$ & $\begin{array}{l}1.280^{*} \\
(0.610)\end{array}$ & $\begin{array}{l}1.670 * * \\
(0.581)\end{array}$ & $\begin{array}{l}0.873 \\
(0.633)\end{array}$ & $\begin{array}{l}0.736 \\
(0.712)\end{array}$ & $\begin{array}{l}0.457 \\
(1.393)\end{array}$ & $\begin{array}{l}0.674 \\
(0.672)\end{array}$ & $\begin{array}{l}2.212 * * \\
(1.008)\end{array}$ \\
\hline$P O P$ & $\begin{array}{l}9.121 \\
(7.989)\end{array}$ & $\begin{array}{l}11.461 * \\
(5.611)\end{array}$ & $\begin{array}{l}8.148 \\
(4.655)\end{array}$ & $\begin{array}{l}-3.093 \\
(4.084)\end{array}$ & $\begin{array}{l}2.307 \\
(3.119)\end{array}$ & $\begin{array}{l}0.933 \\
(1.968)\end{array}$ & $\begin{array}{l}-5.884 \\
(3.708)\end{array}$ & $\begin{array}{l}-12.079 \\
(9.434)\end{array}$ & $\begin{array}{l}9.385 \\
(7.924)\end{array}$ & $\begin{array}{l}7.892 \\
(6.249)\end{array}$ \\
\hline Constant & $\begin{array}{l}-171.435 \\
(136.391)\end{array}$ & $\begin{array}{l}-189.115^{*} \\
(93.768)\end{array}$ & $\begin{array}{l}-156.481 * \\
(78.481)\end{array}$ & $\begin{array}{l}43.231 \\
(67.160)\end{array}$ & $\begin{array}{l}-54.383 \\
(54.489)\end{array}$ & $\begin{array}{l}-17.023 \\
(32.997)\end{array}$ & $\begin{array}{l}98.891 \\
(65.171)\end{array}$ & $\begin{array}{l}0.000 \\
(.)\end{array}$ & $\begin{array}{l}-169.153 \\
(136.982)\end{array}$ & $\begin{array}{l}-155.487 \\
(104.960)\end{array}$ \\
\hline Observations & 630 & 459 & 630 & 483 & 612 & 471 & 528 & 269 & 641 & 641 \\
\hline R-squared within & 0.107 & 0.093 & 0.090 & 0.112 & 0.095 & 0.088 & 0.084 & 0.076 & 0.060 & 0.103 \\
\hline
\end{tabular}

Note: Please see Table 4a. 


\begin{tabular}{|c|c|c|c|c|c|c|c|c|c|c|c|}
\hline 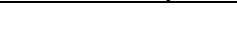 & (1) & (2) & (3) & (4) & (5) & (6) & (7) & (8) & (9) & (10) & (11) \\
\hline & Aggregate & FBT & TW & PCPRP & MM & $\mathrm{OM}$ & TRM & TS & FS & $\mathrm{C}$ & TM \\
\hline \multirow[t]{2}{*}{$I P S$} & -0.050 & $-1.402 *$ & $-1.096 * *$ & $\begin{array}{l}-0.274 \\
\end{array}$ & 0.010 & 0.008 & 0.660 & $\begin{array}{l}-0.687 \\
\end{array}$ & -0.189 & $-1.157 * *$ & 0.099 \\
\hline & $(0.979)$ & $(0.761)$ & $(0.460)$ & $(0.624)$ & $(0.385)$ & $(0.425)$ & (0.979) & $(0.855)$ & (1.034) & $(0.456)$ & $(0.551)$ \\
\hline \multirow[t]{2}{*}{$I N F$} & $0.276^{* *}$ & $0.373 *$ & -0.035 & 0.120 & $0.145^{* *}$ & -0.027 & $0.272 * * *$ & $-0.260 * *$ & $0.472 * * *$ & $-0.095 * *$ & $0.258 * * *$ \\
\hline & $(0.095)$ & $(0.182)$ & $(0.088)$ & $(0.070)$ & $(0.051)$ & $(0.056)$ & $(0.062)$ & $(0.102)$ & $(0.058)$ & $(0.043)$ & $(0.061)$ \\
\hline \multirow[t]{2}{*}{$G D P$} & -0.052 & -0.145 & -0.029 & $0.116^{* *}$ & 0.004 & 0.069 & -0.046 & -0.134 & 0.001 & $0.243^{*}$ & -0.058 \\
\hline & $(0.172)$ & $(0.107)$ & (0.081) & $(0.052)$ & $(0.069)$ & $(0.078)$ & $(0.091)$ & $(0.112)$ & $(0.164)$ & $(0.131)$ & $(0.076)$ \\
\hline \multirow{2}{*}{ TRADE } & -0.014 & -0.002 & $-0.015 * *$ & 0.012 & $-0.010^{*}$ & 0.015 & 0.005 & -0.002 & -0.004 & -0.011 & -0.008 \\
\hline & $(0.012)$ & $(0.017)$ & $(0.007)$ & $(0.007)$ & $(0.005)$ & (0.009) & $(0.007)$ & $(0.009)$ & $(0.012)$ & $(0.007)$ & (0.006) \\
\hline \multirow[t]{2}{*}{ CORTAX } & -0.093 & $-0.168 * *$ & -0.006 & -0.008 & $0.130 * * *$ & 0.005 & -0.015 & $-0.224 * *$ & $-0.137^{*}$ & -0.007 & -0.021 \\
\hline & $(0.076)$ & $(0.066)$ & (0.090) & $(0.054)$ & $(0.040)$ & $(0.032)$ & $(0.020)$ & $(0.092)$ & $(0.070)$ & $(0.018)$ & $(0.042)$ \\
\hline \multirow[t]{2}{*}{$I N D U$} & 0.111 & 0.067 & 0.016 & -0.058 & 0.038 & 0.051 & $0.087 * *$ & 0.074 & $0.126^{*}$ & -0.074 & $0.108 * *$ \\
\hline & $(0.075)$ & $(0.043)$ & $(0.080)$ & $(0.042)$ & $(0.049)$ & (0.038) & $(0.034)$ & (0.044) & $(0.063)$ & $(0.050)$ & $(0.045)$ \\
\hline \multirow[t]{2}{*}{$E X R C$} & $-6.629 * *$ & -6.839 & 0.101 & -2.132 & -2.625 & -1.752 & 1.962 & -4.642 & -3.688 & 5.759 & $-7.719 * *$ \\
\hline & $(2.625)$ & $(4.690)$ & (2.275) & (3.012) & $(2.861)$ & (2.106) & $(2.743)$ & (2.995) & $(2.726)$ & (3.344) & (2.949) \\
\hline \multirow[t]{2}{*}{$E D U C$} & $-0.149 *$ & $-0.285^{* *}$ & 0.090 & 0.037 & 0.003 & -0.060 & $-0.036^{*}$ & 0.012 & -0.145 & -0.042 & -0.078 \\
\hline & $(0.084)$ & (0.118) & $(0.081)$ & $(0.045)$ & $(0.022)$ & $(0.042)$ & $(0.020)$ & $(0.061)$ & $(0.092)$ & $(0.038)$ & $(0.049)$ \\
\hline \multirow[t]{2}{*}{$P S A V T$} & 2.247 & 1.941 & $2.769 * *$ & -0.168 & -0.275 & $-0.852 * *$ & $-1.942 *$ & 1.092 & 1.484 & -0.356 & 0.303 \\
\hline & (2.142) & (1.259) & (1.026) & $(0.814)$ & $(0.384)$ & $(0.294)$ & (1.006) & (1.066) & $(2.321)$ & $(0.676)$ & $(0.710)$ \\
\hline \multirow[t]{2}{*}{ INFRA } & -0.076 & -0.070 & 0.020 & $0.091 *$ & 0.003 & 0.008 & 0.041 & -0.007 & $-0.184 * * *$ & 0.013 & 0.036 \\
\hline & $(0.054)$ & $(0.066)$ & $(0.036)$ & $(0.048)$ & (0.019) & $(0.012)$ & $(0.035)$ & $(0.031)$ & $(0.041)$ & $(0.025)$ & $(0.044)$ \\
\hline \multirow[t]{2}{*}{$E X P$} & $2.147 * *$ & 2.037 & $1.156^{* *}$ & -1.644 & $0.793 *$ & $-0.945^{*}$ & 0.094 & -0.635 & $2.076^{* *}$ & 0.441 & -0.128 \\
\hline & $(0.856)$ & (1.324) & $(0.412)$ & (0.988) & $(0.384)$ & $(0.457)$ & $(0.310)$ & $(0.674)$ & $(0.698)$ & $(0.328)$ & (1.127) \\
\hline \multirow[t]{2}{*}{$P O P$} & $15.123^{*}$ & 20.742 & $-15.178 * *$ & 9.099 & 0.220 & -1.199 & $20.740 * * *$ & 15.131 & $24.587 * * *$ & $6.004^{*}$ & 6.667 \\
\hline & (8.179) & (12.171) & $(6.547)$ & $(6.256)$ & (2.910) & (3.724) & $(4.838)$ & $(9.958)$ & $(7.176)$ & $(3.324)$ & $(5.244)$ \\
\hline \multirow[t]{2}{*}{ Constant } & $-298.317 * *$ & $-388.930 *$ & $249.387 * *$ & -124.797 & -22.695 & 45.484 & $-365.118 * * *$ & -235.641 & $-458.094 * * *$ & $-101.692 *$ & -108.079 \\
\hline & $(125.069)$ & (195.969) & (108.384) & (91.646) & $(50.571)$ & $(63.999)$ & $(83.425)$ & (167.518) & $(110.154)$ & $(55.278)$ & (70.034) \\
\hline Observations & 259 & 142 & 179 & 182 & 237 & 227 & 215 & 210 & 241 & 241 & 259 \\
\hline R-squared within & 0.290 & 0.400 & 0.215 & 0.255 & 0.229 & 0.293 & 0.360 & 0.318 & 0.293 & 0.382 & 0.201 \\
\hline
\end{tabular}

Notes: Please see Table 4a. 
Table 5b Dependent variable EOFDI - US sample.

\begin{tabular}{|c|c|c|c|c|c|c|c|c|c|c|}
\hline & (1) & (2) & (3) & (4) & (5) & (6) & (7) & (8) & (9) & (10) \\
\hline & Aggregate & M & TM & $\mathrm{F}$ & $\mathrm{C}^{\prime}$ & PFM & MA & OM & CET & OI \\
\hline$I P S$ & $\begin{array}{l}0.177 \\
(0.104)\end{array}$ & $\begin{array}{l}-0.010 \\
(0.354)\end{array}$ & $\begin{array}{l}0.063 \\
(0.211)\end{array}$ & $\begin{array}{l}0.032 \\
(0.208)\end{array}$ & $\begin{array}{l}0.192 \\
(0.193)\end{array}$ & $\begin{array}{l}0.230 \\
(0.168)\end{array}$ & $\begin{array}{l}-0.074 \\
(0.264)\end{array}$ & $\begin{array}{l}-0.241 \\
(0.210)\end{array}$ & $\begin{array}{l}0.048 \\
(0.279)\end{array}$ & $\begin{array}{l}0.121 \\
(0.302)\end{array}$ \\
\hline INF & $\begin{array}{l}-0.005 \\
(0.031)\end{array}$ & $\begin{array}{l}0.029 \\
(0.019)\end{array}$ & $\begin{array}{l}-0.015 \\
(0.039)\end{array}$ & $\begin{array}{l}0.015 \\
(0.035)\end{array}$ & $\begin{array}{l}-0.050 * * \\
(0.019)\end{array}$ & $\begin{array}{l}0.047 * * * \\
(0.013)\end{array}$ & $\begin{array}{l}0.004 \\
(0.030)\end{array}$ & $\begin{array}{l}-0.027^{*} \\
(0.013)\end{array}$ & $\begin{array}{l}0.015 \\
(0.022)\end{array}$ & $\begin{array}{l}0.024 \\
(0.032)\end{array}$ \\
\hline$G D P$ & $\begin{array}{l}0.101 \\
(0.079)\end{array}$ & $\begin{array}{l}0.055 \\
(0.076)\end{array}$ & $\begin{array}{l}0.178 * * * \\
(0.055)\end{array}$ & $\begin{array}{l}0.122 * * * \\
(0.037)\end{array}$ & $\begin{array}{l}0.069 \\
(0.045)\end{array}$ & $\begin{array}{l}-0.018 \\
(0.057)\end{array}$ & $\begin{array}{l}0.019 \\
(0.072)\end{array}$ & $\begin{array}{l}0.151 * * \\
(0.061)\end{array}$ & $\begin{array}{l}0.141 * \\
(0.071)\end{array}$ & $\begin{array}{l}-0.023 \\
(0.074)\end{array}$ \\
\hline TRADE & $\begin{array}{l}-0.001 \\
(0.002)\end{array}$ & $\begin{array}{l}0.009 * * * \\
(0.003)\end{array}$ & $\begin{array}{l}0.001 \\
(0.004)\end{array}$ & $\begin{array}{l}0.000 \\
(0.005)\end{array}$ & $\begin{array}{l}0.014 * * * \\
(0.004)\end{array}$ & $\begin{array}{l}-0.002 \\
(0.006)\end{array}$ & $\begin{array}{l}-0.017 * * \\
(0.007)\end{array}$ & $\begin{array}{l}-0.006 \\
(0.006)\end{array}$ & $\begin{array}{l}0.016 * * \\
(0.007)\end{array}$ & $\begin{array}{l}-0.003 \\
(0.004)\end{array}$ \\
\hline CORTAX & $\begin{array}{l}0.017 \\
(0.019)\end{array}$ & $\begin{array}{l}-0.052 \\
(0.053)\end{array}$ & $\begin{array}{l}0.038 * \\
(0.021)\end{array}$ & $\begin{array}{l}0.029 \\
(0.020)\end{array}$ & $\begin{array}{l}-0.034 \\
(0.023)\end{array}$ & $\begin{array}{l}-0.018 \\
(0.027)\end{array}$ & $\begin{array}{l}-0.004 \\
(0.017)\end{array}$ & $\begin{array}{l}-0.040 \\
(0.031)\end{array}$ & $\begin{array}{l}0.102 * * \\
(0.041)\end{array}$ & $\begin{array}{l}0.025 \\
(0.045)\end{array}$ \\
\hline$I N D U$ & $\begin{array}{l}0.025 \\
(0.040)\end{array}$ & $\begin{array}{l}-0.041 \\
(0.026)\end{array}$ & $\begin{array}{l}-0.015 \\
(0.019)\end{array}$ & $\begin{array}{l}-0.079 * * * \\
(0.023)\end{array}$ & $\begin{array}{l}-0.003 \\
(0.021)\end{array}$ & $\begin{array}{l}0.002 \\
(0.031)\end{array}$ & $\begin{array}{l}0.029 \\
(0.028)\end{array}$ & $\begin{array}{l}-0.041 \\
(0.027)\end{array}$ & $\begin{array}{l}0.014 \\
(0.035)\end{array}$ & $\begin{array}{l}0.078^{* *} \\
(0.033)\end{array}$ \\
\hline EXRCHAN & $\begin{array}{l}-2.083 * * \\
(0.723)\end{array}$ & $\begin{array}{l}-0.880 \\
(0.781)\end{array}$ & $\begin{array}{l}-0.927 \\
(0.968)\end{array}$ & $\begin{array}{l}0.942 \\
(0.796)\end{array}$ & $\begin{array}{l}-0.775 \\
(0.772)\end{array}$ & $\begin{array}{l}0.728 \\
(0.733)\end{array}$ & $\begin{array}{l}1.783^{*} \\
(0.917)\end{array}$ & $\begin{array}{l}0.043 \\
(1.035)\end{array}$ & $\begin{array}{l}-0.157 \\
(0.888)\end{array}$ & $\begin{array}{l}-1.347 \\
(0.829)\end{array}$ \\
\hline$E D U C$ & $\begin{array}{l}-0.016 \\
(0.018)\end{array}$ & $\begin{array}{l}0.084 * * \\
(0.034)\end{array}$ & $\begin{array}{l}-0.013 \\
(0.018)\end{array}$ & $\begin{array}{l}0.105^{* *} \\
(0.039)\end{array}$ & $\begin{array}{l}-0.027 \\
(0.019)\end{array}$ & $\begin{array}{l}-0.040^{*} \\
(0.019)\end{array}$ & $\begin{array}{l}0.022 \\
(0.030)\end{array}$ & $\begin{array}{l}-0.065 * * \\
(0.022)\end{array}$ & $\begin{array}{l}0.079 * * * \\
(0.025)\end{array}$ & $\begin{array}{l}0.007 \\
(0.024)\end{array}$ \\
\hline$P S A V T$ & $\begin{array}{l}0.541 * * \\
(0.213)\end{array}$ & $\begin{array}{l}-0.067 \\
(0.377)\end{array}$ & $\begin{array}{l}-0.244 \\
(0.330)\end{array}$ & $\begin{array}{l}-0.006 \\
(0.260)\end{array}$ & $\begin{array}{l}-0.161 \\
(0.214)\end{array}$ & $\begin{array}{l}-0.468 \\
(0.282)\end{array}$ & $\begin{array}{l}0.223 \\
(0.243)\end{array}$ & $\begin{array}{l}-0.108 \\
(0.346)\end{array}$ & $\begin{array}{l}0.142 \\
(0.461)\end{array}$ & $\begin{array}{l}1.378 * * \\
(0.584)\end{array}$ \\
\hline INFRA & $\begin{array}{l}-0.004 \\
(0.008)\end{array}$ & $\begin{array}{l}-0.024 * * \\
(0.009)\end{array}$ & $\begin{array}{l}-0.014 \\
(0.017)\end{array}$ & $\begin{array}{l}-0.003 \\
(0.014)\end{array}$ & $\begin{array}{l}0.001 \\
(0.008)\end{array}$ & $\begin{array}{l}0.023 * \\
(0.013)\end{array}$ & $\begin{array}{l}0.001 \\
(0.017)\end{array}$ & $\begin{array}{l}0.012 \\
(0.014)\end{array}$ & $\begin{array}{l}0.010 \\
(0.019)\end{array}$ & $\begin{array}{l}0.030 * * \\
(0.013)\end{array}$ \\
\hline$E X P$ & $\begin{array}{l}1.300 * * * \\
(0.236)\end{array}$ & $\begin{array}{l}0.871 * * * \\
(0.268)\end{array}$ & $\begin{array}{l}0.550 * * \\
(0.253)\end{array}$ & $\begin{array}{l}0.988 * * \\
(0.394)\end{array}$ & $\begin{array}{l}1.096 * * * \\
(0.210)\end{array}$ & $\begin{array}{l}0.097 \\
(0.322)\end{array}$ & $\begin{array}{l}0.999 * * * \\
(0.319)\end{array}$ & $\begin{array}{l}0.094 \\
(0.140)\end{array}$ & $\begin{array}{l}0.219 \\
(0.551)\end{array}$ & $\begin{array}{l}1.927 * * \\
(0.709)\end{array}$ \\
\hline$P O P$ & $\begin{array}{l}2.903 * * * \\
(0.966)\end{array}$ & $\begin{array}{l}8.427 * * \\
(3.676)\end{array}$ & $\begin{array}{l}2.297 \\
(2.737)\end{array}$ & $\begin{array}{l}0.194 \\
(2.590)\end{array}$ & $\begin{array}{l}11.358 * * * \\
(1.057)\end{array}$ & $\begin{array}{l}4.237^{*} \\
(2.111)\end{array}$ & $\begin{array}{l}-5.517 * * * \\
(1.288)\end{array}$ & $\begin{array}{l}-0.678 \\
(4.505)\end{array}$ & $\begin{array}{l}-9.442 * \\
(5.012)\end{array}$ & $\begin{array}{l}1.263 \\
(3.205)\end{array}$ \\
\hline Constant & $\begin{array}{l}-56.009 * * * \\
(17.496)\end{array}$ & $\begin{array}{l}-150.143 * * \\
(63.423)\end{array}$ & $\begin{array}{l}-40.355 \\
(46.103) \\
\end{array}$ & $\begin{array}{l}-12.499 \\
(42.224) \\
\end{array}$ & $\begin{array}{l}-202.086 * * * \\
(18.935)\end{array}$ & $\begin{array}{l}-72.471 * \\
(35.142)\end{array}$ & $\begin{array}{l}89.543 * * * \\
(22.029)\end{array}$ & $\begin{array}{l}0.000 \\
(.)\end{array}$ & $\begin{array}{l}156.063 * \\
(86.004)\end{array}$ & $\begin{array}{l}-37.099 \\
(51.574)\end{array}$ \\
\hline Observations & 641 & 512 & 637 & 577 & 613 & 570 & 585 & 394 & 641 & 641 \\
\hline R-squared within & 0.350 & 0.143 & 0.211 & 0.120 & 0.283 & 0.110 & 0.136 & 0.072 & 0.122 & 0.277 \\
\hline
\end{tabular}

Note: Please see Table 4a. 
Table 6a Dependent variable OFDI flows (high and low IPS regime) - UK sample.

\begin{tabular}{|c|c|c|c|c|c|c|c|c|c|c|c|}
\hline & (1) & (2) & (3) & (4) & (5) & (6) & (7) & (8) & (9) & (10) & (11) \\
\hline & AGGREGATE & FBT & TW & PCPRP & MM & $\mathrm{OM}$ & TRM & TS & FS & $\mathrm{C}$ & $\mathrm{TM}$ \\
\hline$I P S$ & $\begin{array}{l}-4.225 * * \\
(1.691)\end{array}$ & $\begin{array}{l}1.070 \\
(6.157)\end{array}$ & $\begin{array}{l}-6.174 * * * \\
(1.320)\end{array}$ & $\begin{array}{l}2.555 \\
(6.118)\end{array}$ & $\begin{array}{l}2.722 \\
(1.801)\end{array}$ & $\begin{array}{l}-0.917 \\
(2.010)\end{array}$ & $\begin{array}{l}-3.446^{*} \\
(1.775)\end{array}$ & $\begin{array}{l}-7.206 * * \\
(3.313)\end{array}$ & $\begin{array}{l}3.009 \\
(3.798)\end{array}$ & $\begin{array}{l}1.469 \\
(2.355)\end{array}$ & $\begin{array}{l}-5.554 * \\
(2.654)\end{array}$ \\
\hline $\begin{array}{l}\text { Observations } \\
\text { R-squared within }\end{array}$ & $\begin{array}{l}124 \\
0.280\end{array}$ & $\begin{array}{l}74 \\
0.385\end{array}$ & $\begin{array}{l}85 \\
0.451\end{array}$ & $\begin{array}{l}81 \\
0.293 \\
\end{array}$ & $\begin{array}{l}111 \\
0.225\end{array}$ & $\begin{array}{l}117 \\
0.409\end{array}$ & $\begin{array}{l}112 \\
0.307\end{array}$ & $\begin{array}{l}105 \\
0.361\end{array}$ & $\begin{array}{l}106 \\
0.398\end{array}$ & $\begin{array}{l}107 \\
0.347\end{array}$ & $\begin{array}{l}123 \\
0.241\end{array}$ \\
\hline \multicolumn{12}{|c|}{ Panel B: Low IPS regime } \\
\hline & $\begin{array}{l}\text { (1) } \\
\text { Aggregate }\end{array}$ & $\begin{array}{l}(2) \\
\text { FBT }\end{array}$ & $\begin{array}{l}\text { (3) } \\
\text { TW }\end{array}$ & $\begin{array}{l}\text { (4) } \\
\text { PCPRP }\end{array}$ & $\begin{array}{l}\text { (5) } \\
\text { MM }\end{array}$ & $\begin{array}{l}\text { (6) } \\
\text { OM }\end{array}$ & $\begin{array}{l}\text { (7) } \\
\text { TRM }\end{array}$ & $\begin{array}{l}\text { (8) } \\
\text { TS }\end{array}$ & $\begin{array}{l}\text { (9) } \\
\text { FS }\end{array}$ & $\begin{array}{l}(10) \\
\mathrm{C}\end{array}$ & $\begin{array}{l}\text { (11) } \\
\text { TM }\end{array}$ \\
\hline$I P S$ & $\begin{array}{l}-0.769 \\
(0.742) \\
\end{array}$ & $\begin{array}{l}-1.653 \\
(1.539) \\
\end{array}$ & $\begin{array}{l}1.739 * * * \\
(0.437)\end{array}$ & $\begin{array}{l}-0.483 \\
(1.974) \\
\end{array}$ & $\begin{array}{l}0.709 \\
(1.212) \\
\end{array}$ & $\begin{array}{l}-0.903 \\
(1.098) \\
\end{array}$ & $\begin{array}{l}0.076 \\
(1.263) \\
\end{array}$ & $\begin{array}{l}-1.427 \\
(0.920) \\
\end{array}$ & $\begin{array}{l}-1.750 \\
(1.332) \\
\end{array}$ & $\begin{array}{l}0.888 \\
(1.829) \\
\end{array}$ & $\begin{array}{l}0.644 \\
(2.124) \\
\end{array}$ \\
\hline $\begin{array}{l}\text { Observations } \\
\text { R-squared within }\end{array}$ & $\begin{array}{l}131 \\
0.362\end{array}$ & $\begin{array}{l}97 \\
0.280\end{array}$ & $\begin{array}{l}101 \\
0.358\end{array}$ & $\begin{array}{l}118 \\
0.357\end{array}$ & $\begin{array}{l}127 \\
0.243\end{array}$ & $\begin{array}{l}126 \\
0.160\end{array}$ & $\begin{array}{l}122 \\
0.339\end{array}$ & $\begin{array}{l}108 \\
0.263\end{array}$ & $\begin{array}{l}127 \\
0.370\end{array}$ & $\begin{array}{l}116 \\
0.305\end{array}$ & $\begin{array}{l}131 \\
0.230\end{array}$ \\
\hline
\end{tabular}

Notes: Please see Table 4a. Other independent variables included in the regressions (as in Table 4a) but not reported to conserve space.

Table 6b Dependent variable OFDI flows (high and low IPS regime) - US sample.

Panel A: High IPS regime

\begin{tabular}{|c|c|c|c|c|c|c|c|c|c|c|}
\hline & (1) & (2) & (3) & (4) & (5) & (6) & (7) & (8) & (9) & (10) \\
\hline & Aggregate & M & TM & $\mathrm{F}$ & $\mathrm{C}$ & PFM & MA & OM & CET & OI \\
\hline$I P S$ & $\begin{array}{l}-1.690 \\
(1.754)\end{array}$ & $\begin{array}{l}-0.977 \\
(0.962)\end{array}$ & $\begin{array}{l}1.378 \\
(1.257)\end{array}$ & $\begin{array}{l}-1.283 \\
(1.010)\end{array}$ & $\begin{array}{l}1.496 \\
(1.681)\end{array}$ & $\begin{array}{l}-0.241 \\
(0.867)\end{array}$ & $\begin{array}{l}0.193 \\
(0.887)\end{array}$ & $\begin{array}{l}-0.113 \\
(1.907) \\
\end{array}$ & $\begin{array}{l}1.161 \\
(0.806)\end{array}$ & $\begin{array}{l}-1.539 \\
(1.793) \\
\end{array}$ \\
\hline Observations & 303 & 224 & 300 & 212 & 288 & 235 & 254 & 142 & 308 & 308 \\
\hline R-squared within & 0.138 & 0.155 & 0.116 & 0.184 & 0.138 & 0.104 & 0.160 & 0.160 & 0.165 & 0.143 \\
\hline
\end{tabular}

Panel B: Low IPS regime

\begin{tabular}{|c|c|c|c|c|c|c|c|c|c|c|}
\hline & (1) & (2) & (3) & (4) & (5) & (6) & (7) & (8) & (9) & (10) \\
\hline & Aggregate & M & TM & $\mathrm{F}$ & $\mathrm{C}$ & PFM & MA & $\mathrm{OM}$ & CET & OI \\
\hline$I P S$ & $\begin{array}{l}-0.620 \\
(0.589) \\
\end{array}$ & $\begin{array}{l}0.425 \\
(0.587) \\
\end{array}$ & $\begin{array}{l}-0.476 \\
(0.354) \\
\end{array}$ & $\begin{array}{l}-0.806 \\
(0.727) \\
\end{array}$ & $\begin{array}{l}0.199 \\
(0.457) \\
\end{array}$ & $\begin{array}{l}-0.729 * * \\
(0.324)\end{array}$ & $\begin{array}{l}0.311 \\
(0.569) \\
\end{array}$ & $\begin{array}{l}-1.490 \\
(1.172) \\
\end{array}$ & $\begin{array}{l}-0.084 \\
(0.690) \\
\end{array}$ & $\begin{array}{l}-0.611 \\
(0.638) \\
\end{array}$ \\
\hline Observations & 327 & 235 & 330 & 271 & 324 & 236 & 274 & 127 & 333 & 333 \\
\hline R-squared within & 0.157 & 0.126 & 0.137 & 0.140 & 0.165 & 0.219 & 0.089 & 0.198 & 0.068 & 0.183 \\
\hline
\end{tabular}

Notes: Please see Table 4a. Other independent variables included in the regressions (as in Table 4a) but not reported to conserve space. 
Table 7a Dependent variable EOFDI (high and low IPS regime) - UK sample.

\begin{tabular}{|c|c|c|c|c|c|c|c|c|c|c|c|}
\hline & (1) & (2) & (3) & (4) & $(5)$ & (6) & (7) & (8) & (9) & (10) & (11) \\
\hline & Aggregate & FBT & TW & PCPRP & MM & OM & TRM & TS & FS & C & TM \\
\hline$I P S$ & $\begin{array}{l}-0.335 \\
(1.459) \\
\end{array}$ & $\begin{array}{l}-4.657 \\
(2.924)\end{array}$ & $\begin{array}{l}-0.932 \\
(1.736) \\
\end{array}$ & $\begin{array}{l}-0.273 \\
(1.060) \\
\end{array}$ & $\begin{array}{l}-0.236 \\
(0.455) \\
\end{array}$ & $\begin{array}{l}-1.084 \\
(1.284) \\
\end{array}$ & $\begin{array}{l}1.743 \\
(1.506) \\
\end{array}$ & $\begin{array}{l}-0.217 \\
(1.573) \\
\end{array}$ & $\begin{array}{l}-1.648 \\
(2.536) \\
\end{array}$ & $\begin{array}{l}0.077 \\
(0.824) \\
\end{array}$ & $\begin{array}{l}2.268 \\
(2.252) \\
\end{array}$ \\
\hline $\begin{array}{l}\text { Observations } \\
\text { R-squared within }\end{array}$ & $\begin{array}{l}128 \\
0.316 \\
\end{array}$ & $\begin{array}{l}61 \\
0.806 \\
\end{array}$ & $\begin{array}{l}84 \\
0.455 \\
\end{array}$ & $\begin{array}{l}72 \\
0.605 \\
\end{array}$ & $\begin{array}{l}117 \\
0.477 \\
\end{array}$ & $\begin{array}{l}110 \\
0.364 \\
\end{array}$ & $\begin{array}{l}109 \\
0.425 \\
\end{array}$ & $\begin{array}{l}108 \\
0.450 \\
\end{array}$ & $\begin{array}{l}121 \\
0.363 \\
\end{array}$ & $\begin{array}{l}120 \\
0.678 \\
\end{array}$ & $\begin{array}{l}128 \\
0.280 \\
\end{array}$ \\
\hline \multicolumn{12}{|c|}{ Panel B: Low IPS regime } \\
\hline & $\begin{array}{l}(1) \\
\text { Aggregate }\end{array}$ & $\begin{array}{l}(2) \\
\text { FBT }\end{array}$ & $\begin{array}{l}\text { (3) } \\
\text { TW }\end{array}$ & $\begin{array}{l}(4) \\
\text { PCPRP }\end{array}$ & $\begin{array}{l}\text { (5) } \\
\text { MM }\end{array}$ & $\begin{array}{l}(6) \\
\mathrm{OM}\end{array}$ & $\begin{array}{l}(7) \\
\text { TRM }\end{array}$ & $\begin{array}{l}(8) \\
\text { TS }\end{array}$ & $\begin{array}{l}(9) \\
\text { FS }\end{array}$ & $\begin{array}{l}(10) \\
\mathrm{C}\end{array}$ & $\begin{array}{l}(11) \\
\text { TM }\end{array}$ \\
\hline$I P S$ & $\begin{array}{l}-1.347 \\
(0.815) \\
\end{array}$ & $\begin{array}{l}0.677 \\
(0.905) \\
\end{array}$ & $\begin{array}{l}-1.248 * * * \\
(0.379)\end{array}$ & $\begin{array}{l}0.360 \\
(0.625) \\
\end{array}$ & $\begin{array}{l}-0.104 \\
(0.775) \\
\end{array}$ & $\begin{array}{l}0.751^{*} \\
(0.386) \\
\end{array}$ & $\begin{array}{l}-0.066 \\
(1.086) \\
\end{array}$ & $\begin{array}{l}-0.644 \\
(0.763) \\
\end{array}$ & $\begin{array}{l}0.213 \\
(0.992) \\
\end{array}$ & $\begin{array}{l}-2.023^{* *} \\
(0.747)\end{array}$ & $\begin{array}{l}0.126 \\
(0.779) \\
\end{array}$ \\
\hline $\begin{array}{l}\text { Observations } \\
\text { R-squared within }\end{array}$ & $\begin{array}{l}131 \\
0.477 \\
\end{array}$ & $\begin{array}{l}81 \\
0.564 \\
\end{array}$ & $\begin{array}{l}95 \\
0.485 \\
\end{array}$ & $\begin{array}{l}110 \\
0.332 \\
\end{array}$ & $\begin{array}{l}120 \\
0.278 \\
\end{array}$ & $\begin{array}{l}117 \\
0.475 \\
\end{array}$ & $\begin{array}{l}106 \\
0.549\end{array}$ & $\begin{array}{l}102 \\
0.385 \\
\end{array}$ & $\begin{array}{l}120 \\
0.564 \\
\end{array}$ & $\begin{array}{l}121 \\
0.485 \\
\end{array}$ & $\begin{array}{l}131 \\
0.311 \\
\end{array}$ \\
\hline
\end{tabular}

Notes: Please see Table 4a. Other independent variables included in the regressions (as in Table 4a) but not reported to conserve space.

Table 7b Dependent variable EOFDI (high and low IPS regime) - US sample.

\begin{tabular}{|c|c|c|c|c|c|c|c|c|c|c|}
\hline \multicolumn{4}{|c|}{ Panel A: High IPS regime } & (4) & (5) & (6) & (7) & & & \\
\hline & Aggregate & M & TM & $\mathrm{F}$ & $\mathrm{C}$ & PFM & MA & OM & CET & OI \\
\hline$I P S$ & $\begin{array}{l}-0.113 \\
(0.086) \\
\end{array}$ & $\begin{array}{l}1.483 * * \\
(0.622)\end{array}$ & $\begin{array}{l}0.646^{* * *} \\
(0.272)\end{array}$ & $\begin{array}{l}-0.009 \\
(0.284) \\
\end{array}$ & $\begin{array}{l}0.206 \\
(0.400) \\
\end{array}$ & $\begin{array}{l}-0.020 \\
(0.459) \\
\end{array}$ & $\begin{array}{l}0.420 \\
(0.332) \\
\end{array}$ & $\begin{array}{l}0.244 \\
(0.262) \\
\end{array}$ & $\begin{array}{l}1.127^{* *} \\
(0.464)\end{array}$ & $\begin{array}{l}-0.132 \\
(0.408) \\
\end{array}$ \\
\hline $\begin{array}{l}\text { Observations } \\
\text { R-squared within }\end{array}$ & $\begin{array}{l}308 \\
0.230 \\
\end{array}$ & $\begin{array}{l}248 \\
0.261 \\
\end{array}$ & $\begin{array}{l}308 \\
0.205 \\
\end{array}$ & $\begin{array}{l}277 \\
0.207 \\
\end{array}$ & $\begin{array}{l}292 \\
0.272 \\
\end{array}$ & $\begin{array}{l}276 \\
0.114 \\
\end{array}$ & $\begin{array}{l}288 \\
0.282 \\
\end{array}$ & $\begin{array}{l}195 \\
0.166 \\
\end{array}$ & $\begin{array}{l}308 \\
0.147 \\
\end{array}$ & $\begin{array}{l}308 \\
0.194 \\
\end{array}$ \\
\hline \multicolumn{11}{|c|}{ Panel B: Low IPS regime } \\
\hline & $\begin{array}{l}\text { (1) } \\
\text { Aggregate }\end{array}$ & $\begin{array}{l}(2) \\
M\end{array}$ & $\begin{array}{l}\text { (3) } \\
\text { TM }\end{array}$ & $\begin{array}{l}(4) \\
\mathrm{F}\end{array}$ & $\begin{array}{l}(5) \\
\mathrm{C}\end{array}$ & $\begin{array}{l}(6) \\
\text { PFM }\end{array}$ & $\begin{array}{l}(7) \\
\text { MA }\end{array}$ & $\begin{array}{l}(8) \\
\mathrm{OM}\end{array}$ & $\begin{array}{l}(9) \\
\text { CET }\end{array}$ & $\begin{array}{l}(10) \\
\text { OI }\end{array}$ \\
\hline$I P S$ & $\begin{array}{l}0.349 \\
(0.221) \\
\end{array}$ & $\begin{array}{l}-0.498 \\
(0.302)\end{array}$ & $\begin{array}{l}0.074 \\
(0.292)\end{array}$ & $\begin{array}{l}0.141 \\
(0.339) \\
\end{array}$ & $\begin{array}{l}0.297 \\
(0.260)\end{array}$ & $\begin{array}{l}-0.277 \\
(0.383) \\
\end{array}$ & $\begin{array}{l}-0.126 \\
(0.356)\end{array}$ & $\begin{array}{l}-0.472 * \\
(0.255)\end{array}$ & $\begin{array}{l}0.039 \\
(0.600)\end{array}$ & $\begin{array}{l}0.216 \\
(0.357)\end{array}$ \\
\hline $\begin{array}{l}\text { Observations } \\
\text { R-squared within }\end{array}$ & $\begin{array}{l}333 \\
0.449 \\
\end{array}$ & $\begin{array}{l}264 \\
0.151 \\
\end{array}$ & $\begin{array}{l}329 \\
0.301 \\
\end{array}$ & $\begin{array}{l}300 \\
0.139 \\
\end{array}$ & $\begin{array}{l}321 \\
0.355 \\
\end{array}$ & $\begin{array}{l}294 \\
0.219 \\
\end{array}$ & $\begin{array}{l}297 \\
0.184 \\
\end{array}$ & $\begin{array}{l}199 \\
0.094 \\
\end{array}$ & $\begin{array}{l}333 \\
0.207 \\
\end{array}$ & $\begin{array}{l}333 \\
0.426 \\
\end{array}$ \\
\hline
\end{tabular}

Notes: Please see Table 4a. Other independent variables included in the regressions (as in Table 4a) but not reported to conserve space. 
Table 8a Dependent variable OFDI flows with alternative IPRI index from Property Rights Alliance (PRA) - UK sample.

\begin{tabular}{|c|c|c|c|c|c|c|c|c|c|c|c|}
\hline & (1) & (2) & (3) & (4) & (5) & (6) & (7) & (8) & (9) & (10) & (11) \\
\hline & Aggregate & FBT & TW & PCPRP & MM & OM & TRM & TS & FS & $\mathrm{C}$ & TM \\
\hline IPRI & $\begin{array}{l}-2.945 \\
(2.645)\end{array}$ & $\begin{array}{l}-1.132 \\
(2.667)\end{array}$ & $\begin{array}{l}3.699 * * * \\
(0.817)\end{array}$ & $\begin{array}{l}-2.285^{*} \\
(0.984)\end{array}$ & $\begin{array}{l}-1.145 \\
(1.361) \\
\end{array}$ & $\begin{array}{l}1.261 \\
(1.245)\end{array}$ & $\begin{array}{l}3.872 * * \\
(1.301)\end{array}$ & $\begin{array}{l}0.379 \\
(2.030) \\
\end{array}$ & $\begin{array}{l}-3.461 \\
(2.485) \\
\end{array}$ & $\begin{array}{l}0.773 \\
(1.287)\end{array}$ & $\begin{array}{l}1.330 \\
(1.520)\end{array}$ \\
\hline Observations & 141 & 79 & 85 & 103 & 130 & 132 & 126 & 116 & 135 & 112 & 141 \\
\hline R-squared within & 0.321 & 0.233 & 0.431 & 0.214 & 0.201 & 0.205 & 0.316 & 0.257 & 0.294 & 0.273 & 0.194 \\
\hline
\end{tabular}

Notes: Please see Table 4a. Other independent variables included in the regressions (as in Table 4a) but not reported to conserve space.

Table 8b Dependent variable OFDI flows with alternative IPRI index from Property Rights Alliance (PRA) - US sample.

\begin{tabular}{|c|c|c|c|c|c|c|c|c|c|c|}
\hline & (1) & (2) & (3) & (4) & (5) & (6) & (7) & (8) & (9) & (10) \\
\hline & Aggregate & M & TM & $\mathrm{F}$ & $\mathrm{C}$ & PFM & MA & $\mathrm{OM}$ & CET & OI \\
\hline IPRI & $\begin{array}{l}-0.728 \\
(0.725)\end{array}$ & $\begin{array}{l}-0.329 \\
(0.793)\end{array}$ & $\begin{array}{l}-1.621 * * \\
(0.620)\end{array}$ & $\begin{array}{l}-0.773 \\
(0.559)\end{array}$ & $\begin{array}{l}0.029 \\
(0.458)\end{array}$ & $\begin{array}{l}0.610 \\
(0.498)\end{array}$ & $\begin{array}{l}1.261 \\
(0.679)\end{array}$ & $\begin{array}{l}-1.123 \\
(1.706)\end{array}$ & $\begin{array}{l}-0.113 \\
(0.626)\end{array}$ & $\begin{array}{l}-0.363 \\
(0.487)\end{array}$ \\
\hline Observations & 323 & 238 & 321 & 227 & 311 & 245 & 270 & 175 & 323 & 323 \\
\hline R-squared within & 0.088 & 0.074 & 0.107 & 0.128 & 0.080 & 0.075 & 0.091 & 0.146 & 0.054 & 0.137 \\
\hline
\end{tabular}

Notes: Please see Table 4a. Other independent variables included in the regressions (as in Table 4a) but not reported to conserve space.

Table 9a Dependent variable EOFDI with alternative IPRI index from Property Rights Alliance (PRA) - UK sample.

\begin{tabular}{|c|c|c|c|c|c|c|c|c|c|c|c|}
\hline & (1) & (2) & (3) & (4) & (5) & (6) & (7) & (8) & (9) & (10) & (11) \\
\hline & Aggregate & FBT & TW & PCPRP & MM & $\mathrm{OM}$ & TRM & TS & FS & $\mathrm{C}$ & TM \\
\hline IPRI & $\begin{array}{l}0.378 \\
(1.512)\end{array}$ & $\begin{array}{l}-5.213 * * \\
(1.839)\end{array}$ & $\begin{array}{l}-1.959 * * \\
(0.723)\end{array}$ & $\begin{array}{l}-0.964 \\
(0.947)\end{array}$ & $\begin{array}{l}0.327 \\
(0.805)\end{array}$ & $\begin{array}{l}0.117 \\
(0.249)\end{array}$ & $\begin{array}{l}-0.873 \\
(0.956)\end{array}$ & $\begin{array}{l}0.337 \\
(0.432)\end{array}$ & $\begin{array}{l}0.320 \\
(1.647)\end{array}$ & $\begin{array}{l}2.029 * * \\
(0.819)\end{array}$ & $\begin{array}{l}-2.646^{*} \\
(1.168)\end{array}$ \\
\hline Observations & 142 & 66 & 80 & 83 & 126 & 120 & 114 & 124 & 135 & 127 & 142 \\
\hline R-squared within & 0.282 & 0.468 & 0.387 & 0.323 & 0.229 & 0.403 & 0.297 & 0.314 & 0.181 & 0.394 & 0.224 \\
\hline
\end{tabular}

Notes: Please see Table 4a. Other independent variables included in the regressions (as in Table 4a) but not reported to conserve space.

Table 9b Dependent variable EOFDI with alternative IPRI index from Property Rights Alliance (PRA) - US sample

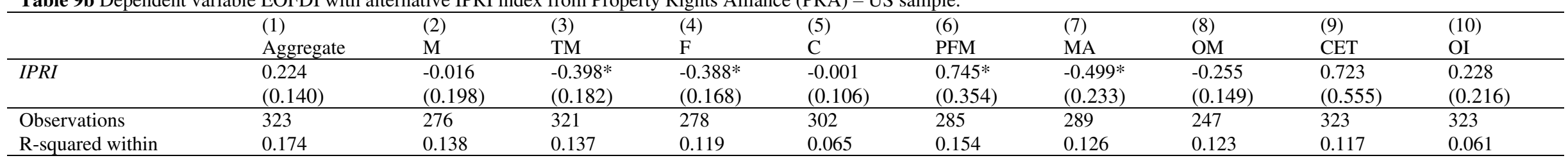

Notes: Please see Table 4a. Other independent variables included in the regressions (as in Table 4a) but not reported to conserve space. 
Table 10 Dependent variable OFDI flows (developed and developing countries) - US sample.

Panel A: Developed countries

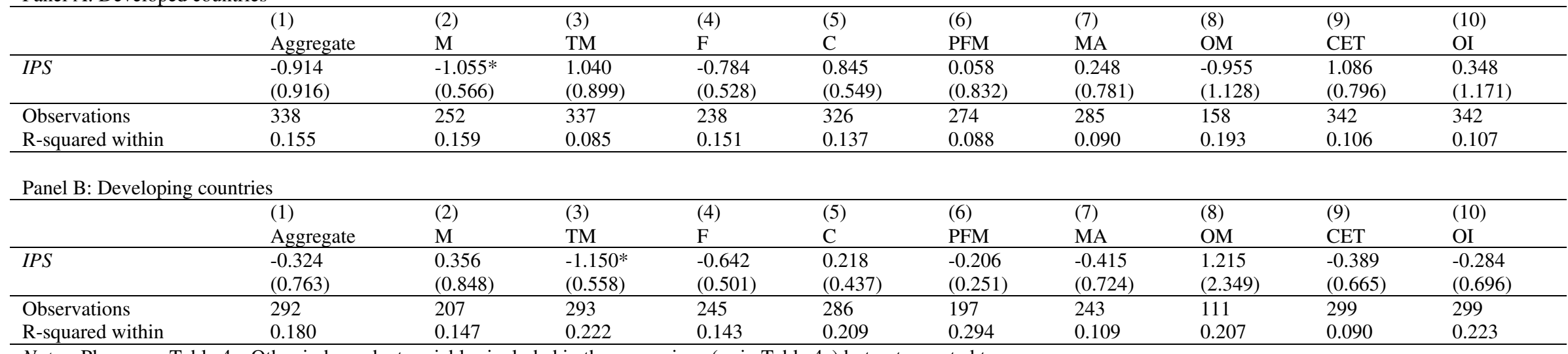

Notes: Please see Table 4a. Other independent variables included in the regressions (as in Table 4a) but not reported to conserve space.

Table 11 Dependent variable EOFDI (developed and developing countries) - US sample.

Panel A: Developed countries

\begin{tabular}{|c|c|c|c|c|c|c|c|c|c|c|}
\hline & (1) & (2) & (3) & (4) & (5) & (6) & (7) & (8) & (9) & (10) \\
\hline & Aggregate & $\mathrm{M}$ & $\mathrm{TM}$ & $\mathrm{F}$ & $\mathrm{C}$ & PFM & MA & $\mathrm{OM}$ & CET & OI \\
\hline$I P S$ & $\begin{array}{l}0.262 * * \\
(0.112)\end{array}$ & $\begin{array}{l}0.899 \\
(0.619)\end{array}$ & $\begin{array}{l}0.743 * * * \\
(0.241)\end{array}$ & $\begin{array}{l}0.684 * * \\
(0.320)\end{array}$ & $\begin{array}{l}0.243 \\
(0.243)\end{array}$ & $\begin{array}{l}0.340 \\
(0.270)\end{array}$ & $\begin{array}{l}0.529 \\
(0.389)\end{array}$ & $\begin{array}{l}-0.045 \\
(0.337)\end{array}$ & $\begin{array}{l}1.402 * * * \\
(0.414)\end{array}$ & $\begin{array}{l}0.185 \\
(0.251)\end{array}$ \\
\hline $\begin{array}{l}\text { Observations } \\
\text { R-squared within }\end{array}$ & $\begin{array}{l}342 \\
0.366 \\
\end{array}$ & $\begin{array}{l}270 \\
0.210 \\
\end{array}$ & $\begin{array}{l}341 \\
0.190 \\
\end{array}$ & $\begin{array}{l}306 \\
0.205 \\
\end{array}$ & $\begin{array}{l}327 \\
0.237 \\
\end{array}$ & $\begin{array}{l}307 \\
0.127\end{array}$ & $\begin{array}{l}313 \\
0.176\end{array}$ & $\begin{array}{l}211 \\
0.180\end{array}$ & $\begin{array}{l}342 \\
0.121\end{array}$ & $\begin{array}{l}342 \\
0.258\end{array}$ \\
\hline \multicolumn{11}{|c|}{ Panel B: Developing countries } \\
\hline & $\begin{array}{l}\text { (1) } \\
\text { Aggregate }\end{array}$ & $\begin{array}{l}\text { (2) } \\
M\end{array}$ & $\begin{array}{l}\text { (3) } \\
\text { TM }\end{array}$ & $\begin{array}{l}(4) \\
F\end{array}$ & $\begin{array}{l}(5) \\
\mathrm{C}\end{array}$ & $\begin{array}{l}(6) \\
\text { PFM }\end{array}$ & $\begin{array}{l}(7) \\
\text { MA }\end{array}$ & $\begin{array}{l}(8) \\
\mathrm{OM}\end{array}$ & $\begin{array}{l}(9) \\
\text { CET }\end{array}$ & $\begin{array}{l}(10) \\
\text { OI }\end{array}$ \\
\hline IPS & $\begin{array}{l}-0.003 \\
(0.222)\end{array}$ & $\begin{array}{l}-0.630^{*} \\
(0.334)\end{array}$ & $\begin{array}{l}-0.049 \\
(0.415)\end{array}$ & $\begin{array}{l}-0.185 \\
(0.373)\end{array}$ & $\begin{array}{l}0.157 \\
(0.317)\end{array}$ & $\begin{array}{l}-0.024 \\
(0.156)\end{array}$ & $\begin{array}{l}-0.634 \\
(0.379)\end{array}$ & $\begin{array}{l}-0.358 \\
(0.285)\end{array}$ & $\begin{array}{l}-0.309 \\
(0.521)\end{array}$ & $\begin{array}{l}-0.009 \\
(0.459)\end{array}$ \\
\hline $\begin{array}{l}\text { Observations } \\
\text { R-squared within }\end{array}$ & $\begin{array}{l}299 \\
0.450 \\
\end{array}$ & $\begin{array}{l}242 \\
0.211 \\
\end{array}$ & $\begin{array}{l}296 \\
0.282 \\
\end{array}$ & $\begin{array}{l}271 \\
0.155 \\
\end{array}$ & $\begin{array}{l}286 \\
0.371 \\
\end{array}$ & $\begin{array}{l}263 \\
0.176 \\
\end{array}$ & $\begin{array}{l}272 \\
0.222 \\
\end{array}$ & $\begin{array}{l}183 \\
0.230 \\
\end{array}$ & $\begin{array}{l}299 \\
0.232 \\
\end{array}$ & $\begin{array}{l}299 \\
0.471 \\
\end{array}$ \\
\hline
\end{tabular}

Notes: Please see Table 4a. Other independent variables included in the regressions (as in Table 4a) but not reported to conserve space. 
Table 12a Dependent variable OFDI - US sample.

\begin{tabular}{|c|c|c|c|c|c|c|c|c|c|c|}
\hline & (1) & (2) & (3) & (4) & (5) & (6) & (7) & (8) & (9) & (10) \\
\hline & Aggregate & M & $\mathrm{TM}$ & $\mathrm{F}$ & $\mathrm{C}$ & PFM & MA & OM & CET & OI \\
\hline$I P S$ & $\begin{array}{l}-0.764 \\
(0.606)\end{array}$ & $\begin{array}{l}-1.379^{*} \\
(0.718)\end{array}$ & $\begin{array}{l}-0.941 * \\
(0.450)\end{array}$ & $\begin{array}{l}-0.951 \\
(0.573)\end{array}$ & $\begin{array}{l}1.073 \\
(0.845)\end{array}$ & $\begin{array}{l}-0.022 \\
(0.801)\end{array}$ & $\begin{array}{l}-0.154 \\
(0.668)\end{array}$ & $\begin{array}{l}1.077 \\
(1.524)\end{array}$ & $\begin{array}{l}-0.092 \\
(0.827)\end{array}$ & $\begin{array}{l}0.106 \\
(0.929)\end{array}$ \\
\hline $\operatorname{IPS}(t-1)$ & $\begin{array}{l}0.358 \\
(0.802)\end{array}$ & $\begin{array}{l}0.976 \\
(0.977)\end{array}$ & $\begin{array}{l}1.576 * * \\
(0.704)\end{array}$ & $\begin{array}{l}0.153 \\
(0.823)\end{array}$ & $\begin{array}{l}-1.032 \\
(0.899)\end{array}$ & $\begin{array}{l}-0.045 \\
(0.671)\end{array}$ & $\begin{array}{l}0.789 \\
(0.692)\end{array}$ & $\begin{array}{l}-2.329 \\
(1.413)\end{array}$ & $\begin{array}{l}0.084 \\
(0.778)\end{array}$ & $\begin{array}{l}-0.514 \\
(1.023)\end{array}$ \\
\hline$I N F$ & $\begin{array}{l}-0.073 \\
(0.077)\end{array}$ & $\begin{array}{l}0.071 \\
(0.094)\end{array}$ & $\begin{array}{l}-0.108^{*} \\
(0.056)\end{array}$ & $\begin{array}{l}0.086 * * \\
(0.035)\end{array}$ & $\begin{array}{l}-0.088 \\
(0.065)\end{array}$ & $\begin{array}{l}0.029 \\
(0.033)\end{array}$ & $\begin{array}{l}-0.053 \\
(0.032)\end{array}$ & $\begin{array}{l}-0.022 \\
(0.093)\end{array}$ & $\begin{array}{l}-0.059 \\
(0.038)\end{array}$ & $\begin{array}{l}-0.056 \\
(0.087)\end{array}$ \\
\hline$G D P$ & $\begin{array}{l}0.193 \\
(0.131)\end{array}$ & $\begin{array}{l}0.150 \\
(0.120)\end{array}$ & $\begin{array}{l}0.251 \\
(0.155)\end{array}$ & $\begin{array}{l}0.099 \\
(0.087)\end{array}$ & $\begin{array}{l}0.079 \\
(0.180)\end{array}$ & $\begin{array}{l}0.050 \\
(0.081)\end{array}$ & $\begin{array}{l}0.052 \\
(0.120)\end{array}$ & $\begin{array}{l}0.302 \\
(0.401)\end{array}$ & $\begin{array}{l}-0.004 \\
(0.129)\end{array}$ & $\begin{array}{l}0.271^{*} \\
(0.137)\end{array}$ \\
\hline TRADE & $\begin{array}{l}-0.014 \\
(0.027)\end{array}$ & $\begin{array}{l}0.011 \\
(0.012)\end{array}$ & $\begin{array}{l}0.021 * \\
(0.010)\end{array}$ & $\begin{array}{l}-0.023 * * \\
(0.009)\end{array}$ & $\begin{array}{l}0.017 \\
(0.010)\end{array}$ & $\begin{array}{l}0.002 \\
(0.009)\end{array}$ & $\begin{array}{l}-0.013 \\
(0.008)\end{array}$ & $\begin{array}{l}-0.012 \\
(0.026)\end{array}$ & $\begin{array}{l}0.031 * \\
(0.017)\end{array}$ & $\begin{array}{l}-0.024 \\
(0.031)\end{array}$ \\
\hline CORTAX & $\begin{array}{l}0.241 * * \\
(0.101)\end{array}$ & $\begin{array}{l}0.072 \\
(0.087)\end{array}$ & $\begin{array}{l}0.076 \\
(0.046)\end{array}$ & $\begin{array}{l}0.142 * * \\
(0.059)\end{array}$ & $\begin{array}{l}-0.042 \\
(0.069)\end{array}$ & $\begin{array}{l}-0.013 \\
(0.066)\end{array}$ & $\begin{array}{l}-0.074 \\
(0.054)\end{array}$ & $\begin{array}{l}-0.166 \\
(0.120)\end{array}$ & $\begin{array}{l}0.082 \\
(0.061)\end{array}$ & $\begin{array}{l}0.139 \\
(0.104)\end{array}$ \\
\hline$I N D U$ & $\begin{array}{l}-0.131 * * \\
(0.054)\end{array}$ & $\begin{array}{l}-0.016 \\
(0.090)\end{array}$ & $\begin{array}{l}-0.095 \\
(0.060)\end{array}$ & $\begin{array}{l}-0.048 \\
(0.062)\end{array}$ & $\begin{array}{l}-0.179 * * \\
(0.072)\end{array}$ & $\begin{array}{l}-0.045 \\
(0.046)\end{array}$ & $\begin{array}{l}-0.002 \\
(0.074)\end{array}$ & $\begin{array}{l}-0.145 \\
(0.228)\end{array}$ & $\begin{array}{l}-0.002 \\
(0.081)\end{array}$ & $\begin{array}{l}-0.101 \\
(0.098)\end{array}$ \\
\hline EXRC & $\begin{array}{l}-4.310 \\
(3.271)\end{array}$ & $\begin{array}{l}-5.350 * * * \\
(1.549)\end{array}$ & $\begin{array}{l}-1.374 \\
(2.226)\end{array}$ & $\begin{array}{l}0.152 \\
(2.053)\end{array}$ & $\begin{array}{l}-2.883 * * \\
(1.340)\end{array}$ & $\begin{array}{l}-2.220 * * \\
(0.916)\end{array}$ & $\begin{array}{l}0.405 \\
(1.753)\end{array}$ & $\begin{array}{l}6.733^{* *} \\
(2.632)\end{array}$ & $\begin{array}{l}-1.099 \\
(2.570)\end{array}$ & $\begin{array}{l}0.416 \\
(2.835)\end{array}$ \\
\hline$E D U C$ & $\begin{array}{l}0.031 \\
(0.030)\end{array}$ & $\begin{array}{l}0.006 \\
(0.069)\end{array}$ & $\begin{array}{l}0.191 * * * \\
(0.058)\end{array}$ & $\begin{array}{l}0.099 \\
(0.071)\end{array}$ & $\begin{array}{l}0.023 \\
(0.052)\end{array}$ & $\begin{array}{l}-0.001 \\
(0.039)\end{array}$ & $\begin{array}{l}0.034 \\
(0.047)\end{array}$ & $\begin{array}{l}0.052 \\
(0.142)\end{array}$ & $\begin{array}{l}0.177 * * * \\
(0.051)\end{array}$ & $\begin{array}{l}0.183 * * * \\
(0.027)\end{array}$ \\
\hline$P S A V T$ & $\begin{array}{l}3.398 * * * \\
(0.739)\end{array}$ & $\begin{array}{l}0.862 \\
(0.776)\end{array}$ & $\begin{array}{l}0.053 \\
(0.587)\end{array}$ & $\begin{array}{l}0.182 \\
(0.372)\end{array}$ & $\begin{array}{l}-0.508 \\
(0.725)\end{array}$ & $\begin{array}{l}-0.760 \\
(0.857)\end{array}$ & $\begin{array}{l}0.408 \\
(0.695)\end{array}$ & $\begin{array}{l}-0.866 \\
(1.293)\end{array}$ & $\begin{array}{l}0.522 \\
(0.834)\end{array}$ & $\begin{array}{l}1.247 * \\
(0.602)\end{array}$ \\
\hline INFRA & $\begin{array}{l}0.060 \\
(0.035)\end{array}$ & $\begin{array}{l}0.082 * * \\
(0.032)\end{array}$ & $\begin{array}{l}0.041 \\
(0.034)\end{array}$ & $\begin{array}{l}-0.017 \\
(0.041)\end{array}$ & $\begin{array}{l}0.098 * * * \\
(0.028)\end{array}$ & $\begin{array}{l}0.012 \\
(0.056)\end{array}$ & $\begin{array}{l}-0.020 \\
(0.039)\end{array}$ & $\begin{array}{l}0.115 \\
(0.067)\end{array}$ & $\begin{array}{l}-0.051 * \\
(0.025)\end{array}$ & $\begin{array}{l}0.082 \\
(0.055)\end{array}$ \\
\hline EXP & $\begin{array}{l}0.493 \\
(0.604)\end{array}$ & $\begin{array}{l}-3.177 * * * \\
(0.611)\end{array}$ & $\begin{array}{l}2.102 * * * \\
(0.649)\end{array}$ & $\begin{array}{l}1.457 * * * \\
(0.386)\end{array}$ & $\begin{array}{l}2.351 * * \\
(0.796)\end{array}$ & $\begin{array}{l}1.199 \\
(0.771)\end{array}$ & $\begin{array}{l}-0.161 \\
(0.659)\end{array}$ & $\begin{array}{l}0.384 \\
(1.606)\end{array}$ & $\begin{array}{l}1.086 \\
(0.809)\end{array}$ & $\begin{array}{l}2.400 * * * \\
(0.803)\end{array}$ \\
\hline$P O P$ & $\begin{array}{l}7.558 \\
(10.899)\end{array}$ & $\begin{array}{l}16.424 * * \\
(6.231)\end{array}$ & $\begin{array}{l}7.448 \\
(6.736)\end{array}$ & $\begin{array}{l}-3.826 \\
(4.971)\end{array}$ & $\begin{array}{l}1.855 \\
(3.813)\end{array}$ & $\begin{array}{l}3.172 \\
(3.315)\end{array}$ & $\begin{array}{l}-5.436 \\
(6.150)\end{array}$ & $\begin{array}{l}-20.205^{* *} \\
(8.248)\end{array}$ & $\begin{array}{l}10.996 \\
(9.526)\end{array}$ & $\begin{array}{l}9.241 \\
(8.629)\end{array}$ \\
\hline $\operatorname{FDISTOCK}(t-1)$ & $\begin{array}{l}0.538 \\
(1.046)\end{array}$ & $\begin{array}{l}2.393 * \\
(1.327)\end{array}$ & $\begin{array}{l}-1.687 * * \\
(0.743)\end{array}$ & $\begin{array}{l}-0.223 \\
(0.583)\end{array}$ & $\begin{array}{l}-0.922 \\
(1.178)\end{array}$ & $\begin{array}{l}-0.461 \\
(0.757)\end{array}$ & $\begin{array}{l}-0.818 \\
(0.646)\end{array}$ & $\begin{array}{l}4.151 * * \\
(1.653)\end{array}$ & $\begin{array}{l}-0.699 \\
(0.957)\end{array}$ & $\begin{array}{l}-0.951 \\
(0.888)\end{array}$ \\
\hline$R \& D$ & $\begin{array}{l}1.063 \\
(1.004)\end{array}$ & $\begin{array}{l}1.046 \\
(1.347)\end{array}$ & $\begin{array}{l}-2.097 * * \\
(0.781)\end{array}$ & $\begin{array}{l}2.016^{* *} \\
(0.798)\end{array}$ & $\begin{array}{l}-0.906^{*} \\
(0.504)\end{array}$ & $\begin{array}{l}-1.968 * * * \\
(0.658)\end{array}$ & $\begin{array}{l}-1.338 \\
(0.844)\end{array}$ & $\begin{array}{l}0.078 \\
(1.358)\end{array}$ & $\begin{array}{l}-0.436 \\
(0.997)\end{array}$ & $\begin{array}{l}-0.176 \\
(0.767)\end{array}$ \\
\hline PATENT & $\begin{array}{l}-0.013 \\
(0.624)\end{array}$ & $\begin{array}{l}-0.992 \\
(0.685)\end{array}$ & $\begin{array}{l}0.370 \\
(0.394)\end{array}$ & $\begin{array}{l}-0.968 * * \\
(0.425)\end{array}$ & $\begin{array}{l}0.102 \\
(0.378)\end{array}$ & $\begin{array}{l}0.202 \\
(0.603)\end{array}$ & $\begin{array}{l}0.667 \\
(0.517)\end{array}$ & $\begin{array}{l}-2.079 * * \\
(0.741)\end{array}$ & $\begin{array}{l}0.529 \\
(0.345)\end{array}$ & $\begin{array}{l}-0.026 \\
(0.702)\end{array}$ \\
\hline Constant & $\begin{array}{l}0.000 \\
(.)\end{array}$ & $\begin{array}{l}-281.981 * * \\
(104.247)\end{array}$ & $\begin{array}{l}-136.862 \\
(112.545) \\
\end{array}$ & $\begin{array}{l}66.066 \\
(82.079) \\
\end{array}$ & $\begin{array}{l}-42.615 \\
(67.615) \\
\end{array}$ & $\begin{array}{l}0.000 \\
(.)\end{array}$ & $\begin{array}{l}103.925 \\
(107.188)\end{array}$ & $\begin{array}{l}327.554^{* *} \\
(134.838)\end{array}$ & $\begin{array}{l}-201.489 \\
(166.036) \\
\end{array}$ & $\begin{array}{l}-173.500 \\
(142.853) \\
\end{array}$ \\
\hline Observations & 521 & 376 & 520 & 392 & 502 & 387 & 436 & 251 & 526 & 526 \\
\hline R-squared within & 0.121 & 0.155 & 0.120 & 0.120 & 0.113 & 0.094 & 0.096 & 0.126 & 0.071 & 0.091 \\
\hline
\end{tabular}




\begin{tabular}{|c|c|c|c|c|c|c|c|c|c|c|}
\hline & (1) & (2) & (3) & (4) & (5) & (6) & (7) & (8) & (9) & (10) \\
\hline & Aggregate & $\mathrm{M}$ & TM & $\mathrm{F}$ & $\mathrm{C}$ & PFM & MA & $\mathrm{OM}$ & CET & OI \\
\hline \multirow[t]{2}{*}{ IPS } & 0.247 & $-0.692 * *$ & 0.390 & -0.253 & $0.673 * *$ & -0.087 & -0.126 & 0.065 & $0.863^{*}$ & $0.779 * *$ \\
\hline & $(0.238)$ & $(0.282)$ & $(0.410)$ & $(0.333)$ & $(0.252)$ & $(0.478)$ & $(0.241)$ & $(0.205)$ & $(0.484)$ & $(0.344)$ \\
\hline \multirow{2}{*}{$\operatorname{IPS}(t-1)$} & -0.024 & $0.713^{* *}$ & 0.056 & 0.356 & -0.464 & $0.736^{*}$ & 0.404 & -0.190 & -0.756 & $-0.580 * *$ \\
\hline & $(0.264)$ & $(0.306)$ & (0.399) & $(0.507)$ & $(0.387)$ & $(0.415)$ & $(0.314)$ & $(0.200)$ & $(0.488)$ & $(0.243)$ \\
\hline \multirow[t]{2}{*}{$I N F$} & -0.022 & $0.044 * *$ & -0.047 & $0.060 * *$ & $-0.071 * * *$ & 0.019 & -0.019 & -0.027 & -0.031 & 0.003 \\
\hline & (0.034) & $(0.019)$ & $(0.032)$ & $(0.024)$ & $(0.024)$ & $(0.012)$ & $(0.030)$ & $(0.021)$ & $(0.035)$ & (0.028) \\
\hline \multirow[t]{2}{*}{$G D P$} & $0.215^{*}$ & 0.000 & $0.236^{* *}$ & $0.145 * * *$ & 0.077 & -0.038 & 0.046 & $0.204 * *$ & 0.129 & 0.083 \\
\hline & (0.114) & $(0.047)$ & $(0.101)$ & $(0.043)$ & $(0.082)$ & $(0.057)$ & $(0.102)$ & $(0.070)$ & (0.106) & $(0.066)$ \\
\hline \multirow[t]{2}{*}{ TRADE } & -0.006 & $0.013 * * *$ & -0.003 & $-0.006 * * *$ & $0.011 * *$ & 0.000 & $-0.019 * *$ & -0.007 & $0.020^{*}$ & $-0.007^{*}$ \\
\hline & (0.004) & $(0.004)$ & (0.005) & $(0.002)$ & $(0.004)$ & (0.006) & $(0.007)$ & (0.008) & (0.010) & (0.003) \\
\hline \multirow[t]{2}{*}{ CORTAX } & 0.006 & -0.017 & 0.018 & 0.027 & $-0.047^{*}$ & -0.024 & $-0.056^{* *}$ & -0.058 & $0.110^{*}$ & 0.057 \\
\hline & $(0.022)$ & $(0.062)$ & $(0.030)$ & $(0.036)$ & $(0.024)$ & $(0.036)$ & $(0.025)$ & $(0.033)$ & $(0.056)$ & $(0.048)$ \\
\hline \multirow[t]{2}{*}{$I N D U$} & -0.008 & -0.018 & -0.040 & $-0.071 * *$ & -0.007 & -0.020 & 0.019 & $-0.062 *$ & -0.002 & $0.055^{*}$ \\
\hline & $(0.052)$ & $(0.022)$ & $(0.029)$ & $(0.027)$ & $(0.030)$ & (0.033) & (0.034) & $(0.034)$ & $(0.042)$ & (0.029) \\
\hline \multirow[t]{2}{*}{$E X R C$} & $-2.253 * *$ & -0.432 & -1.496 & 0.462 & -0.495 & 0.226 & 0.894 & 0.596 & 1.453 & -1.205 \\
\hline & $(0.774)$ & $(1.200)$ & $(0.940)$ & $(0.757)$ & (1.099) & (1.105) & (1.176) & (1.118) & (1.630) & $(0.949)$ \\
\hline \multirow[t]{2}{*}{$E D U C$} & $-0.047 * *$ & $0.106^{* *}$ & -0.023 & 0.089 & -0.023 & 0.003 & $0.067 * *$ & $-0.074 * *$ & $0.106^{* *}$ & 0.004 \\
\hline & $(0.017)$ & $(0.037)$ & $(0.022)$ & $(0.052)$ & $(0.024)$ & $(0.026)$ & $(0.023)$ & $(0.029)$ & $(0.041)$ & $(0.027)$ \\
\hline \multirow[t]{2}{*}{$P S A V T$} & $0.860 * * *$ & 0.536 & 0.201 & 0.036 & 0.126 & 0.097 & 0.118 & -0.337 & 0.623 & $1.534^{*}$ \\
\hline & $(0.264)$ & $(0.441)$ & $(0.351)$ & $(0.336)$ & $(0.280)$ & $(0.365)$ & $(0.370)$ & $(0.532)$ & $(0.769)$ & $(0.716)$ \\
\hline \multirow[t]{2}{*}{ INFRA } & $0.025^{* *}$ & $-0.050 *$ & 0.003 & 0.013 & 0.008 & 0.024 & 0.029 & 0.023 & 0.004 & $0.036 * *$ \\
\hline & $(0.010)$ & $(0.024)$ & $(0.014)$ & $(0.026)$ & $(0.012)$ & $(0.016)$ & $(0.020)$ & $(0.014)$ & $(0.036)$ & $(0.015)$ \\
\hline \multirow[t]{2}{*}{$E X P$} & $1.241 * * *$ & -0.454 & 0.500 & 0.554 & $1.694 * * *$ & 0.276 & $0.504 *$ & 0.101 & 0.014 & $1.604 * * *$ \\
\hline & $(0.328)$ & $(0.472)$ & $(0.374)$ & $(0.453)$ & $(0.280)$ & $(0.470)$ & $(0.269)$ & $(0.312)$ & $(0.742)$ & $(0.468)$ \\
\hline \multirow[t]{2}{*}{$P O P$} & $5.162 * * *$ & $9.474 * *$ & 4.194 & 0.001 & $14.348^{* * *}$ & 4.281 & $-4.125^{*}$ & -0.607 & -7.824 & 2.435 \\
\hline & $(1.380)$ & $(3.554)$ & (3.763) & (3.907) & $(1.146)$ & (2.756) & (2.181) & (5.617) & (6.080) & (3.766) \\
\hline \multirow[t]{2}{*}{$\operatorname{FDISTOCK}(t-1)$} & -0.164 & $1.188 * * *$ & -0.400 & 0.540 & $-1.044 * * *$ & -0.800 & -0.109 & -0.205 & -0.551 & -0.082 \\
\hline & $(0.280)$ & $(0.330)$ & $(0.250)$ & $(0.337)$ & $(0.112)$ & $(0.475)$ & $(0.267)$ & (0.406) & $(0.626)$ & $(0.366)$ \\
\hline \multirow[t]{2}{*}{$R \& D$} & $0.580 * *$ & 0.737 & -0.806 & 0.517 & 0.384 & $-1.890 * * *$ & 0.470 & -0.126 & $-1.925 * *$ & -0.087 \\
\hline & $(0.270)$ & $(0.551)$ & $(0.490)$ & $(0.353)$ & $(0.387)$ & $(0.424)$ & $(0.569)$ & $(0.586)$ & $(0.801)$ & $(0.325)$ \\
\hline \multirow[t]{2}{*}{ PATENT } & $-0.435 * *$ & $0.790 *$ & $-0.444 * * *$ & -0.533 & 0.245 & 0.398 & $-0.455^{* * *}$ & -0.172 & 0.096 & 0.036 \\
\hline & $(0.156)$ & $(0.383)$ & $(0.146)$ & $(0.319)$ & $(0.193)$ & $(0.350)$ & $(0.139)$ & $(0.311)$ & $(0.368)$ & $(0.211)$ \\
\hline \multirow[t]{2}{*}{ Constant } & $-89.988 * * *$ & 0.000 & 0.000 & -8.469 & 0.000 & -70.212 & $73.541 *$ & 21.992 & 138.999 & -54.123 \\
\hline & $(25.095)$ & (.) & (.) & $(64.296)$ & (.) & $(45.734)$ & $(36.331)$ & $(98.832)$ & $(104.577)$ & $(62.068)$ \\
\hline $\mathrm{N}$ & 526 & 419 & 524 & 475 & 504 & 462 & 477 & 348 & 526 & 526 \\
\hline R-squared within & 0.413 & 0.200 & 0.271 & 0.131 & 0.331 & 0.161 & 0.142 & 0.095 & 0.132 & 0.288 \\
\hline
\end{tabular}

Note: Please see table 4a. 